\title{
Operational implementation of the burned area component of the Copernicus Climate Change Service: from MODIS 250m to OLCI 300m data
}

Joshua Lizundia-Loiola ${ }^{1}$, Magí Franquesa ${ }^{1}$, Martin Boettcher ${ }^{2}$, Grit Kirches ${ }^{2}$, M. Lucrecia Pettinari ${ }^{1}$, 5 Emilio Chuvieco $^{1}$

${ }^{1}$ Environmental Remote Sensing Research Group, Department of Geology, Geography and the Environment, Universidad de Alcalá, Calle Colegios 2, Alcalá de Henares, 28801, Spain

${ }^{2}$ Brockmann Consult GmbH, Chrysanderstr 1, 21029 Hamburg, Germany

Correspondence to: Joshua Lizundia-Loiola (joshua.lizundia@uah.es)

10 Abstract. This paper presents a new global, operational burned area (BA) product at $300 \mathrm{~m}$, called C3SBA10, generated from Sentinel-3 Ocean and Land Colour Instrument (OLCI) near-infrared (NIR) reflectance and Moderate Resolution Imaging Spectroradiometer (MODIS) thermal anomaly data. This product was generated within the Copernicus Climate Change Service (C3S). Since C3S is a European service, it aims to use extensively the European Copernicus satellite missions, named Sentinels. Therefore, one of the components of the service is adapting previous developed algorithms to the

15 Sentinel sensors. In the case of BA datasets, the precursor BA dataset (FireCCI51), which was developed within the European Space Agency's (ESA) Climate Change Initiative (CCI), was based on the 250m-resolution NIR band of the MODIS sensor, and the effort has been focused on adapting this BA algorithm to the characteristics of the Sentinel-3 OLCI sensor, which provides similar spatial and temporal resolution to MODIS. As the precursor BA algorithm, the OLCI's one combines thermal anomalies and spectral information in a two-phase approach, where first thermal anomalies with a high

20 probability of being burned are selected, reducing commission errors, and then a contextual growing is applied to fully detect the BA patch, reducing omission errors. The new BA product includes the full time-series of S3 OLCI data (2017-present). Following the specifications of the FireCCI project, the final datasets are provided in two different formats: monthly fullresolution continental tiles, and monthly global files with aggregated data at 0.25 -degree resolution. To facilitate the use by global vegetation dynamics and atmospheric emission models several auxiliary layers were included, such as land cover and

25 cloud-free observations. The C3SBA10 product detected $3.77 \mathrm{Mkm}^{2}, 3.59 \mathrm{Mkm}^{2}$, and $3.63 \mathrm{Mkm}^{2}$ of annual BA from 2017 to 2019, respectively. The quality and consistency assessment of C3SBA10 and the precursor FireCCI51 was done for the common period (2017-2019). The global spatial validation was performed using reference data derived from Landsat-8 images, following a stratified random sampling design. The C3SBA10 showed commission errors between 14-22\% and omission errors from 50 to $53 \%$, similar to those presented by the FireCCI51 product. The temporal reporting accuracy was 30 also validated using 4.7 million active fires. $88 \%$ of the detections were made within 10 days after the fire by both products. The spatial and temporal consistency assessment performed between C3SBA10 and FireCCI51 using four different grid 
https://doi.org/10.5194/essd-2020-399

Preprint. Discussion started: 14 January 2021

(c) Author(s) 2021. CC BY 4.0 License.

sizes $\left(0.05^{\circ}, 0.10^{\circ}, 0.25^{\circ}\right.$, and $\left.0.50^{\circ}\right)$ showed global, annual correlations between 0.93 and 0.99 . This high consistency between both products ensures a global BA data provision from 2001 to present. The datasets are freely available through the Copernicus Climate Data Store (CDS) repository (DOI: https://doi.org/10.24381/cds.f333cf85, Lizundia-Loiola et al.

35 (2020a)).

\section{Introduction}

Interactions between climate and fire are bidirectional. On the one hand, climate impacts fire regimes (Marlon et al., 2013; Turco et al., 2019b), mostly by modifying temperature and precipitation patterns, which in turn impact fire ignition and behaviour through changes in soil and fuel moisture, vegetation productivity, and fuel availability (Andela and van der Werf,

40 2014;Daniau et al., 2013;Enright et al., 2015;Moritz et al., 2012;Bowman et al., 2020). On the other hand, biomass burning is a critical source of aerosols and greenhouse gases that directly affect atmospheric chemistry (van der Werf et al., 2017; Ward et al., 2012) and carbon budgets (Yue et al., 2020;Poulter et al., 2015) and carbon stocks (Friedlingstein et al., 2020). Emissions from fires increase aerosol optical depth, modifying the radiation budget and, thus, warming the lower atmosphere, which affects regional temperature, clouds, and precipitation patterns (Tosca et al., 2010;Tosca et al., 2014).

45 Fires have important ecological implications as well. They are a critical component supporting biodiversity (Kelly and Brotons, 2017), since they alter vegetation composition, structure, and succession (Bowman et al., 2009). Furthermore, wildfires have significant societal impacts, particularly when extreme events occur as a result of climate anomalies. Large damages on people's lives, health and infrastructures have been observed in recent catastrophic fire seasons of Southern Europe, Australia and Western USA (Bowman et al., 2020; Turco et al., 2019b).

50 The Global Climate Observing System (GCOS) programme promotes international efforts to generate a wide range of observations required for monitoring the Earth's climate system (https://gcos.wmo.int/en/home, last accessed December 2020). These observations are commonly categorized under the umbrella of Essential climate variables (ECV) (Bojinski et al., 2014), which critically contribute to the characterisation of Earth's climate system. The European Space Agency (ESA) responded to the GCOS needs with the Climate Change Initiative (CCI) in 2009. The CCI programme was initially focused

55 on 13 GCOS ECVs (now extended to $21 \mathrm{ECVs}$ ), each of them addressed within a dedicated project that encompassed algorithm development, validation, uncertainty characterisation, and large-scale EO data processing among other tasks (Plummer et al., 2017).

Fire disturbance is one of the initial ECVs tackled within the CCI programme through the FireCCI project (https://climate.esa.int/en/projects/fire/, last accessed December 2020). GCOS identified burned area (BA) as the key

60 parameter for defining the Fire Disturbance ECV, complemented by active fires and fire radiative power (FRP) (GCOS, 2016). Therefore, the principal objective of FireCCI is to produce long-term time series of global BA data. Although BA information is required for a wide range of applications (Chuvieco et al., 2019;Mouillot et al., 2014), the FireCCI project is mainly oriented towards climate modellers and, hence, BA data have been mainly used for the characterisation of fire 
https://doi.org/10.5194/essd-2020-399

Preprint. Discussion started: 14 January 2021

(c) Author(s) 2021. CC BY 4.0 License.

\section{(c) (i)}

emissions for atmospheric chemistry modelling (Seiler and Crutzen, 1980;van der Werf et al., 2017) and the parameterization of fire-enabled Dynamic Global Vegetation Models (DGVMs) (Forkel et al., 2017;Forkel et al., 2019; Hantson et al., 2016; Hantson et al., 2020). These applications strongly benefit from an extended temporal coverage of BA datasets, while assuring their temporal and spatial consistency (Heil, 2019).

The FireCCI project has developed three BA algorithms to generate BA data from moderate-resolution sensors. The three resulting BA products were named FireCCI41, based on Envisat satellite's Medium Resolution Imaging Spectrometer (MERIS) data (Alonso-Canas and Chuvieco, 2015), covering the period 2005-2011 at 300m spatial resolution; the FireCCI50 product, based on 250m resolution Moderate Resolution Imaging Spectroradiometer's (MODIS) bands (Chuvieco et al., 2018), and an improved version of this product, named FireCCI51, which extends from 2001 to 2019 (Lizundia-Loiola et al., 2020b). These three algorithms are based on a hybrid approach, combining Near-Infrared (NIR) and Red reflectance with active fires detections obtained from thermal anomalies. The three algorithms also followed a two-phase approach (seed

75 detection + region growing), although the newest one overcame the previous version's weaknesses by improving BA detection using active fire cluster-based thresholds (Lizundia-Loiola et al., 2020b).

A few years after the ESA CCI programme started, the European Commission launched the Copernicus programme, which included different services mostly based on Earth observation data. One of them is the Copernicus Climate Change Service (C3S, https://climate.copernicus.eu/, last accessed December 2020). C3S has been developed as an operational service that

80 routinely produces datasets for more than $20 \mathrm{ECV}$ s (Thépaut et al., 2018). It builds upon the research and development carried out by the worldwide scientific community, especially the European one. In this regard, the C3S programme is now in charge of the operational processing of several ECVs, many of which were generated within the CCI programme (Thépaut et al., 2018). Since C3S is a European service, it aims to use extensively the European Copernicus satellite missions, named Sentinels. Therefore, one of the components of the service is adapting previous developed algorithms to the Sentinel sensors.

85 In the case of BA datasets, the precursor BA dataset (FireCCI51) was based on 250m resolution bands of the MODIS sensor (Lizundia-Loiola et al., 2020b) and, hence, the effort has been focused on adapting this BA algorithm to the characteristics of the Ocean and Land Colour Instrument (OLCI) on board Sentinel-3 (S3), which provides similar spatial and temporal resolution to MODIS. Built upon the experience of the Envisat's MERIS sensor, OLCI was initially designed for ocean monitoring, but it has been successfully used in several land applications (Zhang et al., 2020;Pastor-Guzman et al., 2020).

90 MERIS was the basis of the abovementioned FireCCI41 BA dataset (Alonso-Canas and Chuvieco, 2015), and therefore, it was expected that OLCI would show similar BA detection capabilities. In fact, due to its better temporal resolution (3-day revisit time for MERIS and 1 day for OLCI, when the two S3 are available), it was expected that OLCI would detect BA more accurately than MERIS.

This paper aims to present the new operational, global BA product OLCI C3S Burned Area v1.0 (hereafter C3SBA10)

95 developed under the framework of the C3S, based on OLCI data. The manuscript briefly describes the original algorithm (FireCCI51) in Section 2.1, while the pre-processing, adaptation, uncertainty characterisation, generation, and distribution of the operational BA dataset are explained in Sections 2.2-2.5. The operational dataset (2017-present) was designed to be as 
https://doi.org/10.5194/essd-2020-399

Preprint. Discussion started: 14 January 2021

(c) Author(s) 2021. CC BY 4.0 License.

consistent as possible with its predecessor FireCCI51 (2001-2019) to ensure that multi-decadal analyses can benefit from both datasets uninterruptedly. Hence, quality assessment was performed in two stages. First, the period 2017-2019 was spatially validated using reference data obtained from multitemporal Landsat- 8 images and temporally using active fire information (Section 2.6). Then, an inter-comparison was performed between FireCCI51 and C3SBA10 datasets to provide users with insights about the consistency between the two products, pointing out similarities and discrepancies (Section 2.7). The results of the BA detections for the common time series (2017-2019) as well as the quality assessment of the product are presented in Section 3, followed by the discussion and conclusion (Section 4 and Section 5, respectively).

\subsection{Original burned area algorithm}

The original FireCCI51 algorithm was initially developed for the Terra MODIS NIR band at 250m spatial resolution and, therefore, some minor changes were introduced to adapt it to the new sensor (Section 2.3). A detailed description of the original algorithm can be found on Lizundia-Loiola et al. (2020b), although a simplified description is provided in the

110 following paragraphs and in Figure 1.

The FireCCI51 algorithm follows a hybrid approach that takes advantage of combining active fires and spectral information. It first creates monthly composites of NIR reflectance by searching for minimum NIR reflectance while maximising the proximity to the fire date determined by the nearest active fire. Then, a second variable is computed from the relative NIR drop of consecutive composites. The third variable is generated from neighbour active fires that are close enough in space

$115(<1875 \mathrm{~m})$ and time (<4 days) to be aggregated into spatio-temporal clusters (STC) (Lizundia-Loiola et al., 2020b).

These variables are the basis for the two-phase hybrid approach used by the FireCCI51 algorithm. The aim of the first step is to minimise commission errors by selecting seed-pixels with a high probability of being burned (seed-phase). NIR and relative NIR drop thresholds are obtained for each STC based on specific burned and unburned samples. The burned sample is defined by the active fires that belong to the STC. The unburned one is composed by pixels from the vicinity of the STC,

120 i.e. those located within a strip between 10 and $20 \mathrm{~km}$ from the STC. Active fires are filtered out using in each case the thresholds of the corresponding STC to obtain seed-pixels. Then, a contextual growing is applied from each seed-pixel, being the growing stop criteria the thresholds of the STC to which the seed-pixel belongs (growing-phase). The purpose of this second step is to minimise omission errors by detecting the full burned patch.

The final result is a monthly classification where each burned pixel is labelled by its day of detection, i.e. the day of the year from which the NIR value of the monthly composite was extracted.

The adaptation of FireCCI51 to C3SBA10 BA algorithm was done in two steps. First, it was checked whether any parameter that controlled the original BA algorithm needed to be adapted. Second, the most suitable input band among the different NIR bands of the OLCI sensor was selected. Both aspects depend on the datasets used as input for the BA algorithm and, hence, Section 2.2 provides information about them. This is used in Section 2.3 to justify how the adaptation was performed. 
https://doi.org/10.5194/essd-2020-399

Preprint. Discussion started: 14 January 2021

(c) Author(s) 2021. CC BY 4.0 License.

\subsection{Input data}

\subsubsection{OLCI Surface directional reflectances}

The S3 satellites were designed to provide operational ocean and land observation services (https://sentinel.esa.int/web/sentinel/missions/sentinel-3, last accessed December 2020). They represent the continuity of the European Remote Sensing satellites (ERS-1 and ERS-2), the Envisat and the Satellite Pour l'Observation de la Terre (SPOT). S3 have a low $(814.5 \mathrm{~km})$, high inclination $\left(98.65^{\circ}\right)$, sun-synchronous Earth-orbit. With a period of $\sim 101$ minutes, S3 need 27 days to complete a full cycle (385 orbits). The first satellite, called S3A, was launched in February 2016 and the second one, called S3B, was launched two years later. The orbit of S3B is identical to S3A but flies $\pm 140^{\circ}$ out of phase to improve revisit time. The design life of S3 is 7.5 years (consumables for 12 years), but the mission is expected to last longer, as two additional satellites will be launched during the first years of the current decade.

140 The OLCI sensor, one of S3's main payloads, is a push-broom imaging spectrometer composed of five cameras that are $12.6^{\circ}$ tiled in western direction to mitigate potential sun-glint effects (https://sentinel.esa.int/web/sentinel/technicalguides/sentinel-3-olci, last accessed December 2020). It has a swath width of $1270 \mathrm{~km}$ (Field-of-View $=68.6^{\circ}$ ) and it offers global coverage at $300 \mathrm{~m}$ every $\sim 2$ or $\sim 1$ day depending on the number of satellites available (S3A or S3A+S3B, respectively) and application (ocean or land). The OLCI instrument includes the same 15 spectral bands of MERIS (400-

$1451020 \mathrm{~nm}$ ), and six extra channels that were included to improve the atmospheric and aerosol corrections (Table 1). All this information is included in the OL_1_EFR Level 1B product, which provides full resolution, calibrated, ortho-geolocated and spatially re-sampled Top-of-Atmosphere (TOA) radiances (https://sentinel.esa.int/web/sentinel/user-guides/sentinel-3olci/product-types/level-1b, last accessed December 2020).

This product was converted to surface directional reflectance (SDR) using an automated pre-processing chain that generates

150 OLCI Level 3 SDR. The first module of the chain converted the TOA spectral radiance to the apparent SDR. Then, a pixel identification module calculates a set of pixel classification attributes, like clear, cloud, snow/ice, cloud shadows, etc. The third module is an atmospheric correction algorithm, which included the correction for the absorbing and scattering effects of atmospheric gases, in particular ozone, oxygen and water vapour, of the scattering of air molecules (Rayleigh scattering) and the correction of absorption and scattering due to aerosol particles. The atmospheric correction including aerosol retrieval

155 was first developed in the GlobAlbedo project (GlobAlbedo, 2013). The last processing module of the pre-processing chain (compositing and mosaicking) was applied to retrieve the final Level 3 products. These 1-day SDR composites were derived from an input set of single satellite observations (i.e., SDR and pixel classification data described previously). Thus, those single observations were (i) reprojected onto a Plate Carrée grid, (ii) temporally aggregated for given binning cells (tiles), and (iii) mosaicked based on the binning cells onto a Level 3 product of 10x10 degrees tiles (Figure 2). 
https://doi.org/10.5194/essd-2020-399

Preprint. Discussion started: 14 January 2021

(c) Author(s) 2021. CC BY 4.0 License.

\subsubsection{Auxiliary data}

Information on active fires was used to guide both the seed and the growing phase of the BA algorithm. The input product was the MODIS MCD14ML Collection 6, which provides global monthly information on the location of thermal anomalies using both Terra and Aqua MODIS bands (Giglio et al., 2018b) at $1 \mathrm{~km}$ spatial resolution. The MCD14ML product is provided in ASCII format and one of its attributes specifies the presumed origin of the thermal anomaly: 0 for presumed vegetation fire, 1 for active volcano, 2 for other static land sources, and 3 for offshore thermal anomalies. Among these categories, only those anomalies labelled as 0 were considered. This product was selected as it was the one used by the original FireCCI51 algorithm (Lizundia-Loiola et al., 2020b).

Global, annual land cover (LC) maps, which were provided by the Land Cover C3S, were used as well (https://cds.climate.copernicus.eu/cdsapp\#!/dataset/satellite-land-cover?tab=overview, last accessed December 2020). LC

170 production was transferred from $\mathrm{CCI}$ to $\mathrm{C} 3 \mathrm{~S}$ at the same time as the BA datasets, which meant that the same working group was the responsible of adapting the algorithms. So, although the FireCCI51 BA algorithm used the latest LC v2.0.7 of CCI project (ESA, 2017), the LC version v2.1.1 from C3S was considered fully consistent with its predecessor (Defourny et al., 2020). In fact, the annual land cover maps from 1992 to 2015 developed within the CCI were brokered to C3S and extended for the years 2016-2018. Data at 333m spatial resolution from PROBA-V was used to generate the global, annual LC maps

175 of 2016, 2017, and 2018. The use of the LC products had two main objectives. On the one hand, they were used to mask unburnable areas, i.e. bare areas, urban areas, water bodies, and permanent snow and ice classes, to decrease the amount of data to be processed. On the other hand, they were used to report which land cover class was burned. Since the idea was to characterise the situation before the fire, the LC map that was applied in each year was the one prior to the BA analysis, e.g. LC of 2016 was used for the BA processing of 2017. This product was selected to 1) ensure consistency with the original

180 algorithm, 2) ensure consistency within the C3S, and 3) use a product that offered LC information at a similar spatial resolution of the input OLCI SDR.

\subsection{Adapted burned area algorithm}

The adaptation was based on the analysis of the same study sites that were used for the FireCCI algorithm (Lizundia-Loiola et al., 2020b) (Figure 2) as they encompassed a wide variety of vegetation types and fire regimes. This study sites were the

185 thirteen equivalent $10 \times 10^{\circ}$ degree OLCI tiles of the MODIS standard, sinusoidal tiles used in the development of the original FireCCI51 algorithm (Lizundia-Loiola et al., 2020b). Six of those tiles were distributed in regions where fire perimeters from different official services were available. The western coast of US, in California, was chosen as representative of temperate forests, where fire perimeters were obtained through the Fire and Resource Assessment Program (FRAP, http://frap.fire.ca.gov/ last accessed on December 2020). Fire perimeters from the Northern Australian Fire Information

190 (NAFI, http://www.firenorth.org.au/nafi3/, last accessed on December 2020) served to assess the adapted algorithm's performance in tropical savanna. Finally, as an example of the boreal forests, perimeters of fires larger than 200 ha were 
https://doi.org/10.5194/essd-2020-399

Preprint. Discussion started: 14 January 2021

(c) Author(s) 2021. CC BY 4.0 License.

(c) (i)

downloaded from the Canadian National Fire Database (CNFDB, http://cwfis.cfs.nrcan.gc.ca/ha/nfdb, last accessed December 2020). The remaining seven tiles were used to visually check that no major problems arise when applying the adapted algorithm to the new sensor, e.g. border effects in Central Africa, problems on the thresholds due to contrasted fire regimes within the same tile in Angola or region-growing problems due to high BA/active fire ratios found near Kazakhstan. The adaptation of the algorithm to OLCI and its integration in the C3S operational system were carried out during 2018 and, hence, the training dataset's temporal coverage was limited to 2017, when only S3A was available.

Most of the parameters that control the FireCCI51 BA algorithm were independent from the base sensor used to detect BA, such as the time-gap used to temporally aggregate active fires or the absolute thresholds that were fixed for global detection (Lizundia-Loiola et al., 2020b). However, parameters linked to a distance might be affected by the spatial resolution of both the surface reflectance product and the active fire product. The fixed distance used to spatially aggregate active fires into a same cluster (Section 2.1), for example, might depend on the spatial resolution of the input active fires product. Higher spatial resolution thermal bands can lead to higher densities of active fire pixels within a same burned patch (Oliva and Schroeder, 2015; Schroeder et al., 2014) and, therefore, the distance that is needed to spatially aggregate them could be smaller. In this case, there was no difference between the input active fire product used in the development of the original algorithm and the adapted one (Section 2.2.2). Similarly, the distances used to define the unburned region around active fire clusters (Section 2.1) depend on both the spatial resolution of the input surface reflectance and the density of active fires per burned patch. The spatial resolution of the base sensor directly affects the number of surface reflectance pixels that fall into the unburned strip and, hence, could be used to estimate the thresholds. The same distance could imply the selection of much more pixels when the spatial resolution of the input sensor was high while in coarser resolutions could lead to a number of pixels that may be insufficient. The difference of the spatial resolution of the input sensors used in the original algorithm $(250 \mathrm{~m})$ and the adapted one $(300 \mathrm{~m})$ were considered sufficiently similar to keep the parameters that defined the unburned strip.

Since the original FireCCI51 BA algorithm and, hence, the adapted one, needed only one input NIR band, the most suitable

215 OLCI band (Table 1) had to be selected. In the case of MODIS it was not necessary to make such selection because it offers only one NIR band (Lizundia-Loiola et al., 2020b). Based on a sensitivity analysis of the MERIS bands carried out by Oliva et al. (2011) during the development of FireCCI41, two NIR bands were considered candidates to be the input of the adapted BA algorithm: Oa12 centred at $753.75 \mathrm{~nm}$ and Oa17 centred at $865 \mathrm{~nm}$ (Table 1). These spectral bands were the most sensitive bands for BA detection, although no significant differences were found between them (Oliva et al., 2011).

The adapted BA algorithm was run two times with the training dataset, i.e. thirteen study sites and year 2017, using in each process one of the mentioned bands. The assessment against the services' fire perimeters showed slightly more accurate results of the $865 \mathrm{~nm}$ band over the $753.75 \mathrm{~nm}$ one (same commission error and $\sim 1 \%$ lower omission error). None of the bands showed unexpected anomalies in the rest of the tiles. Taking into account these results and the similarity between the OLCI $865 \pm 10 \mathrm{~nm}$ band and the MODIS $858.5 \pm 17.5 \mathrm{~nm}$ band used in the original FireCCI51 BA algorithm, which implied 
https://doi.org/10.5194/essd-2020-399

Preprint. Discussion started: 14 January 2021

(c) Author(s) 2021. CC BY 4.0 License.

(c) (i)

225 a greater consistency between the algorithms, the OLCI's $865 \mathrm{~nm}$ NIR band was selected as main input for the adapted algorithm.

\subsection{Product generation}

The adapted algorithm was processed in a monthly basis for each $10^{\circ} \times 10^{\circ}$ tile and, hence, the raw outputs were provided per month and tile. Pre-processing and BA processing took advantage of the independence of tiles and were produced in parallel

for multiple tiles. BA processing needed a time series of two prior composites to detect the NIR drops, and it required active fire data as seeds for the growing step, which introduced constraints for sequential processing of the time series. These raw outputs were formatted, following mainly the specifications of the FireCCI project (Chuvieco et al., 2017), to obtain the pixel and grid products that were delivered to the final users in NetCDF4 format. The former provided the original BA classification at the original spatial resolution $(300 \mathrm{~m})$ distributed in six continental tiles (Figure 3). The latter computed a

235 global aggregated summary of the raw results at $0.25^{\circ}$ spatial resolution. Both the pixel and grid products provided auxiliary layers suggested by the project end-users, including the land cover that was burned, and the uncertainty, fraction of observed area and burnable area (Table 2).

A total of 273 tiles that encompass the main burnable areas of the Earth, except from Antarctica, some small islands and regions northern than $80^{\circ}$ latitude, were processed. The C3SBA10 extended the spatial coverage provided by the FireCCI51

240 dataset. The northern latitudes between $70^{\circ}$ and $80^{\circ} \mathrm{N}$ of North America and Greenland not processed before were included since rare fire events were observed in the last years in far northern latitudes (Amos, 2019;Evangeliou et al., 2019). This change affected the original bounding box of the Area 1 of the pixel product defined by Chuvieco et al. (2017) within the FireCCI, whose eastern border was extended from $50^{\circ} \mathrm{W}$ to $26^{\circ} \mathrm{W}$ in C3SBA10 (Figure 3).

The operational dataset was processed since January 2017, ensuring up to three years of overlap (2017-2019) between the

245 FireCCI51 and C3SBA10 products. The delivery frequency of the operational product ranged from three to six months depending on the availability of the MODIS active fire MCD14ML product.

\subsection{Uncertainty characterisation}

Uncertainty characterisation is increasingly demanded by the end-users of BA products since it greatly helps the parameterization of climate models (Heil, 2019). Although important advances have been made in the last years regarding uncertainty characterisation of ECVs (Merchant et al., 2017;Mittaz et al., 2019; Sayer et al., 2019), methods to standardise the generation of this variable are still needed (Chuvieco et al., 2019). Therefore, the CS3BA10 algorithm follows the same approach used in the FireCCI51 product. Four input variables related to different phases of the original algorithm were used to compute the estimation of BA detection uncertainty: monthly NIR composite (NIR), monthly relative NIR drop (Rel $\Delta \mathrm{NIR}$ ), number of valid observations in the first 10 post-fire days (obs) and the distance to the nearest seed-pixel (dist).

255 The uncertainty was computed using a logistic regression. Based on those four variables and the results of 2008 of the study sites that were used to develop the original algorithm, the final coefficients of the regression were obtained. 
https://doi.org/10.5194/essd-2020-399

Preprint. Discussion started: 14 January 2021

(c) Author(s) 2021. CC BY 4.0 License.

(c) (i)

In the case of the adapted C3SBA10 algorithm, the coefficients of the logistic regression were updated (Eq. 1) using the four input variables and results of the training dataset described in Section 2.3:

$p b=\frac{1}{1+e^{c}} \quad c=-(4.068-0.002926 \cdot N I R+0.003942 \cdot \operatorname{Rel} \Delta N I R-0.01303 \cdot$ obs $-17.29 \cdot$ dist $)$

\subsection{Validation}

\subsubsection{Spatial assessment}

The spatial accuracy assessment was conducted for the period 2017-2019 for both the FireCCI51 and C3SBA10 products. An independent reference BA dataset derived from Landsat-8 OLI imagery was produced in compliance with the CEOS LPVS stage 3 validation requirements (Morisette et al., 2006), which implies a rigorous statistical selection of reference sites representing diverse global conditions. Hence, for each calendar year 100 sample units were randomly selected using a stratified random sampling design. The sampling units were spatially defined by the Thiessen scene areas (TSAs) constructed by Cohen et al. (2010) and Kennedy et al. (2010) from the Landsat-frames World Reference System 2 (WRS-2). TSAs enable the partition of the earth's surface into non-overlapping spatial units, allowing the computation of unbiased estimators (Gallego, 2005).

270 To ensure that sampled units were distributed across the main biogeographic regions, a first level of stratification was applied based on the biomes defined by the ecoregions2017 map (Dinerstein et al., 2017). The original 14 biomes were aggregated into 8 major biomes, i.e. boreal forest, deserts and xeric shrublands, Mediterranean, temperate forest, temperate savanna, tropical forest, tropical savanna, and tundra (Figure 4). A second level of stratification was applied based on the FireCCI51 BA extent for each calendar year. Thus, each TSA within each biome and year was assigned to a high or low BA stratum following the approach of Padilla et al. (2014). Then, the sample's allocation within the 16 resulting strata (8 biomes x 2 high-low strata) was established proportionally to $N_{h} \sqrt{\overline{B A}_{h}}$, where $N_{h}$ is the number of units in stratum $h$ and $\overline{B A}_{h}$ is the mean mapped BA for stratum $h$ (Padilla et al., 2017).

The reference data for the selected sites were obtained from pairs of Landsat-8 images using a semi-automatic classification algorithm (Bastarrika et al., 2014), followed by a visual inspection to confirm the correct identification of burned patches.

280 Consecutive pairs of images were used to obtain long temporal reference data, covering several months, the entire fire season or the whole year, depending on the image availability. These long temporal reference data allow for an extended temporal overlapping between reference and BA datasets, which makes it possible to improve the spatial accuracy assessment of the BA products, minimizing the impact of the product's temporal reporting accuracy (Section 2.6.2) in the spatial accuracy estimates (Franquesa et al., 2020b).

285 Accuracy metrics were computed based on the error matrix, which is widely used by the scientific community for thematic accuracy assessment (Congalton, 1991). This matrix was derived from the cross tabulation of reference data and the BA products. The metrics used to assess the product accuracy were the Dice coefficient (DC) (Dice, 1945), the relative bias 
https://doi.org/10.5194/essd-2020-399

Preprint. Discussion started: 14 January 2021

(c) Author(s) 2021. CC BY 4.0 License.

(relB) and the commission (Ce) and omission (Oe) errors. DC measures the similarity between the two sets of data; the higher its value, the more the accuracy of the burned category. The relB informs about the bias of the BA product relative to the reference BA, negative relB means BA product underestimation and positive relB, overestimation. Ce refers to the burned area mapped by the BA product but not classified as burned in the reference data, and Oe to the burned area in the reference data not mapped in the BA product. All the accuracy metrics and their associated standard errors were estimated for the whole population applying the formulas described in Padilla et al. (2014) and Padilla et al. (2015).

\subsubsection{Temporal reporting accuracy assessment}

295 A validation of the temporal reporting accuracy of the products was performed as well. Unlike the assessment of the spatial accuracy, which is already addressed in the previous section, the assessment of the temporal accuracy aims to show how accurately the day-of-burn (JD in Table 2) is determined by the BA product. Then, following the approach of Boschetti et al. (2010), the day-of-detection reported by the active fires (Section 2.2.2) was used as ground truth and compared with the dayof-detection reported by the corresponding pixel of the global BA product. These differences where then analysed per biome as well.

\subsection{Consistency assessment}

The estimates of accuracy metrics provided by the validation exercise provide an objective, valuable information regarding the spatial and temporal accuracy of the validated products. However, along with the spatial and temporal accuracy, consistency between products is also of primary interest for multi-decadal analyses, e.g. climate modelling (Chuvieco et al., 2019;Heil, 2019). From this perspective, the C3SBA10 operational product cannot be understood as a unique, independent dataset, but as a continuation of its predecessor FireCCI51 product, ensuring uninterrupted global BA estimations from 2001 to present. To account for the similarities and differences that can arise between both datasets spatial and temporal trends of BA were compared.

A fundamental step when comparing global BA datasets is to define both spatially and temporally the comparison grid that

will be used to aggregate the information. Although different spatial and temporal comparison units can be found in the literature (Boschetti et al., 2004;Giglio et al., 2010;Humber et al., 2018;Turco et al., 2019a), in this case the requirements of some of the most relevant applications of global BA datasets were used to determine the comparison framework (Chuvieco et al., 2019; Heil, 2019). However, in most cases, different applications use different spatial and temporal analysis units. The "fire model intercomparison project" (FireMIP), for example, which systematically compares different fire-enabled DGVMs, uses global, monthly BA data aggregated at $0.5^{\circ}$ spatial resolution for model benchmarking (Hantson et al., 2016). Statistical analyses that target at identifying factors that control fire patterns at global and regional scales commonly require monthly BA data aggregated at $0.25^{\circ}$ or coarser spatial resolutions (Andela and van der Werf, 2014;Bistinas et al., 2013;Forkel et al., 2019;Knorr et al., 2014). The Global Fire Emission Database (van der Werf et al., 2017), one of the most widely used inventories in atmospheric chemistry modelling, provides global emissions derived from BA in monthly, daily and 3-hourly 
https://doi.org/10.5194/essd-2020-399

Preprint. Discussion started: 14 January 2021

(c) Author(s) 2021. CC BY 4.0 License.

(c) (i)

temporal scales at $0.25^{\circ}$ resolution. However, several global fire emission databases are already available at $0.1^{\circ}$ (e.g. Kaiser et al. (2012) updated) and even $0.05^{\circ}$ (e.g. Kuenen et al. (2014)) following the increasing spatial resolution of some global atmospheric chemistry models (Aleksankina et al., 2018;Hu et al., 2018). Thus, it was decided to aggregate BA information into four different geographic grid cell sizes, i.e. $0.05^{\circ}, 0.1^{\circ}, 0.25^{\circ}$, and $0.5^{\circ}$, in a monthly and annual basis.

The results were aggregated spatially into eight biomes as well, following the first stratification of the validation exercise.

325 Four comparison cases were identified: biome-specific monthly BA, biome-specific annual BA, global monthly BA and global annual BA. A total of 1404 scatterplots (3 years x $(12$ monthly +1 annual) x (eight biomes +1 global) x 4 spatial resolutions) were generated based on these comparison cases and the four comparison grids defined above for the analysed years (2017-2019). A linear regression was calculated for each one (Humber et al., 2018;Turco et al., 2019a). Three metrics were used to determine the agreement of the products for a given case. The slope of the regression line was used to analyse

330 the bias, the correlation coefficient ( $r$ ) was used to determine the agreement between products and the root mean square error (RMSE) was used to account for the dispersion of the estimations.

\section{Results}

\subsection{Trends on global burned area}

More than three years (2017 - present) of S3 OLCI data were processed to generate the C3SBA10 global BA product. A total of $27310^{\circ} \times 10^{\circ}$ tiles were needed to cover almost all the burnable areas on the Earth. The algorithm results were summarised and published in pixel (300 m resolution) and grid (0.25-degree resolution) products, using in both the NetCDF4 format. Figure 5 shows the annual accumulated grid BA product for the year 2019 while Figure 6 shows the latitudinal and seasonal contribution of BA for the same year. The amount of BA detect per biome for the three complete natural years can be found in Table 3 .

340 The C3SBA10 product detected 3.77, 3.68, and 3.59 Mkm2 of BA for the years 2017, 2018 and 2019, respectively. The main land cover contributor to global BA was tropical savanna, which had burned $2.8 \mathrm{Mkm}^{2}$ per year (Table 3), representing between 74 and $78 \%$ of global burns. Tropical forest had between 9 and $11 \%$ of total BA (average $0.35 \mathrm{Mkm} 2$ ). Almost all the BA of these biomes was located on a relatively small latitudinal band between $20^{\circ} \mathrm{N}$ and $20^{\circ} \mathrm{S}$ (Figure 5 and Figure 6) that covers part of South America, Central America, Africa, South East Asia, Indonesia and the northern part of Australia.

345 Among these tropical regions several studies have shown that the African savannas are responsible of around 70\% of global BA, followed by the Australian ones, the Brazilian Cerrado and the Orinoquia region in Colombia and Venezuela (Chuvieco et al., 2018;Chuvieco et al., 2016;Giglio et al., 2018a;Lizundia-Loiola et al., 2020b;Roy et al., 2008; van der Werf et al., 2017). In the case of tropical forest, the impacts of deforestation fires on agricultural frontiers can be observed in South America and SE Asia (Chen et al., 2013;van der Werf et al., 2008;van der Werf et al., 2010). A lesser contribution, but still 350 important, comes from the peatland areas of Kalimantan and Sumatra in Indonesia. 
https://doi.org/10.5194/essd-2020-399

Preprint. Discussion started: 14 January 2021

(c) Author(s) 2021. CC BY 4.0 License.

The influence of the dry season in these tropical biomes is quite evident, with a marked fire period from November to March in the Northern Hemisphere, and from June to October in the Southern hemisphere (Figure 6). This trend slightly differs in South East Asia where the fire season continues until May.

Another significant belt of fire activity can be found in the temperate forest and grasslands of the Northern hemisphere

(Figure 5), with relative maximum around $50^{\circ} \mathrm{N}$ (Figure 6). The C3SBA10 detected that on average the accumulated contribution to the global fire activity of these biomes was $0.27 \mathrm{Mkm} 2(7.5 \%)$. Most of this BA comes from the grasslands on the Asian steppe, which is dominated by large fires, although there is also an important agricultural activity (Hall et al., 2016;Zhu et al., 2017). The central plain of United States also exhibits fire activity linked to croplands as well as the forest areas of the north-western territories. In the southern hemisphere, the BA derived from the extreme wildfires of 2019-2020 in the temperate forest of south-eastern Australia (Bowman et al., 2020) is noticeable in Figure 5. The monthly variability of BA in temperate areas is marked by both human agricultural practices and dry summer conditions, leading to two separated fire activity periods: one in March-April and the other in July-August.

The deserts and xeric shrublands' amount of BA detected by the C3SBA10 product showed a similar contribution to that of temperate areas, although with much more inter annual variability. The BA on 2017 was $0.26 \mathrm{MKm} 2$ while on 2019 this

365 number decreased by a half $(0.11 \mathrm{Mkm} 2)$ (Table 3$)$. Two areas on the Earth are responsible of most of this BA: central and southern Kazakhstan are affected by large fires in summer (July-August) while the xeric shrublands and grasslands of central and western Australia show fire activity from October to January.

In the highest latitudes $\left(>60^{\circ} \mathrm{N}\right)$, the boreal forest showed a clear increasing trend in BA for the three-year period when the C3SBA10 product was computed, from 61,173 km2 in 2017 to $90,503 \mathrm{~km} 2$ in 2019 (50\% increase). In the Tundra region,

370 BA showed even higher increases, as in 2019 the product estimated 6 times more BA than the previous year $(13,044 \mathrm{~km} 2$ versus 1,697 km2, respectively) (Table 3). In fact, in 2019 the contribution of these two biomes was almost as much as that of temperate forest. Figure 6 shows how the fire season in the northern latitudes has a clear seasonal pattern, with highest activity in the Summer months (July-August).

Finally, BA on Mediterranean areas showed a significant contrast between the BA of $2018(8,884 \mathrm{~km} 2)$ and the other two

375 years (24,975 and 27,421 km2 in 2017 and 2019, respectively). This inter-annual variation seems to be related to the extreme fire seasons of Portugal in 2017 and in 2019.

\subsection{Validation}

\subsubsection{Spatial assessment}

Table 4 shows the estimated accuracy measures and their standard errors (SE) for the validation dataset. The Dice coefficient 380 varied from 0.59 in $2017(\mathrm{SE}=0.03)$ and $2019(\mathrm{SE}=0.04)$ to $0.64(\mathrm{SE}=0.03)$ in 2018. These values were similar to those obtained for the FireCCI51 product, although this one showed higher accuracy for the years 2017 and 2018, but not significantly higher for 2019 (Table 4). The availability of more images due to the presence of two S3 satellites can explain 
https://doi.org/10.5194/essd-2020-399

Preprint. Discussion started: 14 January 2021

(c) Author(s) 2021. CC BY 4.0 License.

why 2019 was the most similar year. In general terms, C3SBA10 showed similar (2017 and 2019) or lower (2018) commission errors (Ce) and higher omission errors (Oe) than FireCCI51 through the three-year period. Both products showed negative relative bias for all the years, indicating a systematic underestimation of BA, which is common to other global BA datasets (Boschetti et al., 2019).

Although three years are not enough to extract significant conclusions about the temporal trends of accuracy, a similar behaviour can be observed in both products. Thus, the year that presented the highest accuracy metrics in one product also it did in the other product.

\subsubsection{Temporal reporting accuracy assessment}

About 4.7 million of active fires were used to estimate the temporal reporting accuracy of the three-year period of both products (Figure 7). On average (2017-2019) the results of the C3SBA10 showed that for deserts and xeric shrubland, both tropical and temperate savanna and Mediterranean biomes more than $90 \%$ of burned pixels were detected within the first 10 days after the fire (Table A1). This proportion was slightly lower in temperate and tropical forest where $80 \%$ and $86 \%$ of the pixels were labelled within 10 days of detection, respectively. The less accurate biomes were the boreal ones, where only the $70 \%$ (forest) and $69 \%$ (tundra) of the burned pixels were detected within the 10-day period. Although this period could be reasonable for some applications (e.g. dynamic vegetation modelling) there are other applications where it is important to know the precise date of burn. The analysis showed that, on average, only in both savannas and desert and xeric shrubland biomes C3SBA10 was able to detect within 0- or 1-day difference more than $20 \%$ of the cases. This accuracy significantly increased if the difference was set to a maximum of 3-days difference, where all biomes double the number of cases that were detected within this accuracy.

The comparison between products showed that the temporal reporting accuracy is quite similar, having little or no impact the availability of more S3 images in 2019. In fact, for all forest biomes and tundra C3SBA10 provides a slightly more accurate reporting of the date of burn (Figure 7).

\subsection{Consistency assessment}

The relative differences on the amount of BA detected by each product are presented in Table 3. Table 5 shows the consistency metrics (correlation coefficient (r), slope and RMSE) at global and annual scale for the three-years period and the four comparison grid sizes. Figure 8 and Figure 9 show the spatial agreements between FireCCI51 and C3SBA10 for the year 2019.

410 The global BA detected by the predecessor version FireCCI51 was $0.65 \mathrm{Mkm} 2,0.56 \mathrm{Mkm} 2,0.28 \mathrm{Mkm} 2$ higher than that one detected by the C3SBA10 product from 2017 to 2019, respectively. Almost all the disparities in terms of total BA can be explained considering the differences shown by both products in tropical savanna (see slope in Figure 8b), where C3SBA10 detected $0.49 \mathrm{Mkm} 2,0.46 \mathrm{Mkm} 2,0.26 \mathrm{Mkm} 2$ less BA, respectively in the 3 years of the series. The availability of both S3 and, hence, a higher temporal resolution, had a significant impact in the amount of BA detected by the C3SBA10 in those 
https://doi.org/10.5194/essd-2020-399

Preprint. Discussion started: 14 January 2021

(c) Author(s) 2021. CC BY 4.0 License.

415 biomes where fire activity is frequent. Thus, the difference between both products was reduced more than a half in tropical forest, temperate savanna, desert and xeric shrubland, and temperate forest and almost a half in tropical savanna (Table 3). In 2019, if tropical savanna was not considered, only $30,000 \mathrm{~km} 2$ of BA were underestimated by the C3SBA10 versus those of the FireCCI51. This underestimation was partially compensated by the detection of more BA $(5,305 \mathrm{~km} 2)$ in boreal forest and tundra.

420 Even though the annual BA detected by the global BA products differs through the study period, the correlation coefficient (r) showed a significant agreement between them at all comparison grid sizes (Table 5). For instance, the $r$ value at the finest comparison resolution $\left(0.05^{\circ}\right)$ was found to be 0.937 in the year with less agreement (2017) and 0.952 in the year with the highest agreement (2019). This agreement increases if the spatial resolution of the comparison is decreased reaching a $0.99 \mathrm{r}$ value for all the years at $0.5^{\circ}$ grid size. However, the slope shows a clear bias towards FireCCI51, pointing an

425 underestimation of the C3SBA10 product at global and annual scale, confirming the differences in the accuracy metrics shown above.

There is a clear increase on the agreement between products in 2019 as well. The correlation metric is the highest in that year (from 0.95 at $0.05^{\circ}$ to 0.99 at $0.50^{\circ}$ grid resolutions), as well as the slope (from 0.88 at $0.05^{\circ}$ to 0.91 at $0.50^{\circ}$ grid resolutions), which means an increase in the amount of BA detected by the C3SBA10. The RMSE is also the lowest for that year, 430 indicating that the availability of more images from both Sentinels makes the differences smaller. That is why a more detailed analysis of the results of 2019 was conducted to better understand the spatial and temporal trends of the discrepancies between the products.

Through the eight biomes the lowest correlations at annual scale were those of deserts and xeric shrublands with an $\mathrm{r}=0.86$ at $0.05^{\circ}$ grid resolution (Figure 8e). Tropical savanna showed the highest annual agreement with correlations from 0.96 (at $\left.4350.05^{\circ}\right)$ to $0.99\left(\right.$ at $\left.0.50^{\circ}\right)$. However, it had the highest RMSE $\left(2.28 \mathrm{~km}^{2}\right.$ at $\left.0.05^{\circ}\right)$ due to the large amount of BA per grid cell. Boreal forest and tundra show a very high agreement as well, with correlation coefficients between 0.94 and 0.98 for all grid sizes and the lowest RMSE, i.e. $0.27 \mathrm{~km}^{2}$ for boreal forest and $0.14 \mathrm{~km}^{2}$ for tundra at $0.05^{\circ}$. The rest of the biomes presented $\mathrm{r}$ values between $0.87-0.89$ at $0.05^{\circ}$ spatial resolution and above 0.90 from $0.10^{\circ}$ upwards.

The two biomes that showed to be unbiased or with a little bias towards C3SBA10 were those located at highest latitudes 440 (boreal and tundra) with slope values near to 1. The rest of the biomes showed an underestimation of the C3SBA10, although in different proportion. Temperate forest and savannas, for instance, had a slope around 0.88 at $0.05^{\circ}$ grid size, while at $0.50^{\circ}$ it increased up to 0.97 for forest and 0.94 for savanna. The most noticeable underestimation was linked to the Mediterranean (Figure 8f) biome (maximum slope of 0.80 at $0.50^{\circ}$ grid resolution). The rest of biomes presented slopes ranging from 0.8 to 0.9 .

445 At monthly scale (Figure 8) the agreement between products changes depending on the month. Undoubtedly, the more stable biome through the year is tropical savanna (Figure 8b), since it is the most frequently burned biome and where most of the global BA is located. The lowest $r$ is found in those months that contribute less to annual BA, i.e. February, March, April and May, with correlations from 0.86 to 0.89 at the finest comparison resolution, respectively. The rest of the months showed 
https://doi.org/10.5194/essd-2020-399

Preprint. Discussion started: 14 January 2021

(c) Author(s) 2021. CC BY 4.0 License.

(c) (i)

correlations above 0.92 at $0.05^{\circ}$ grid size, being higher in the rest of the comparison resolutions. In fact, at $0.50^{\circ}$ the lowest correlation, which was found in April, showed a value higher than 0.95. A systematic underestimation of the C3SBA10 below $25 \%$ of the annual BA was noticeable through all the grid cells that belong to tropical savanna (Figure 9), which was traduced in slopes between 0.83 (April) and 0.90 (October) at $0.05^{\circ}$ spatial resolution. The influence of tropical savanna is clear in the global metrics, which can in some cases obscure subjacent trends in other biomes.

In most cases, the correlation increases with the proportional contribution to the annual BA. This was the case of boreal forest (Figure 8g) and tundra (Figure 8h) whose peak months clearly matches the summer months, i.e. July and August, which are responsible of the $70 \%$ and $77 \%$ annual BA in those biomes, respectively, and, at the same time, showed the highest agreement $(r>0.91$ and slope $>0.92)$. However, not all biomes have a marked unimodal fire season since they encompass different continents and hemispheres and, therefore, fire activity is affected by diverse climatic and human conditions. In the case of deserts and xeric shrubland biome (Figure 8e) two separate peaks can be found, one in January ( $20 \%$ of annual BA, $r=0.83$, slope $=0.92$ at $0.05^{\circ}$ grid size $)$ and another in July ( $19 \%$ of annual BA, $r=0.92$, slope $=0.88$ at $0.05^{\circ}$ ). Something similar occurs in tropical forests (Figure $8 \mathrm{a}$ ) where January ( $13 \%$ of annual BA, r=0.87, slope $=0.77$ at $0.05^{\circ}$ ) and August $(14 \%$ of annual $\mathrm{BA}, \mathrm{r}=0.92$, slope $=0.88$ ) have the maximum monthly BA values. The tropical savanna shows two clear fire seasons as well (Figure $8 b$ ), following the dry seasons of each hemisphere.

The agreement shown between C3SBA10 and FireCCI51 is not as stable in the case of temperate and Mediterranean biomes. In the former case there is a clear discrepancy in the monthly contribution of April to the annual BA. In the case of temperate forest (Figure 8c), the monthly contribution corresponds to $21.3 \%$ for C3SBA10 while FireCCI51 estimated it at $16.8 \%$. The same occurs in the temperate savanna (Figure 8d) where the contribution increases from $20.4 \%$ (FireCCI51) to 26.8\% (C3SBA10). However, this discrepancy affected mainly the RMSE, which is much higher for this month than for the rest of the months in both biomes (RMSE $=0.44 \mathrm{~km}^{2}$ in savanna and RMSE $=0.27 \mathrm{~km}^{2}$ in forest at $0.05^{\circ}$ grid size). In the Mediterranean biome (Figure 8f), from July to November there is a significant increase in the bias towards FireCCI51, losing the stability shown in the first half of the year, and with slope values as low as 0.51, e.g. in the case of October.

\section{Discussion}

After adapting the original FireCCI51 algorithm to the characteristics of the C3SBA10, we found that the spatial and temporal trends in global BA of the two products showed consistent temporal and spatial trends. Most differences were observed in the first two years of the time series (2017 and 2018) when only one S3 satellite was operating, and therefore the temporal resolution of OLCI (2-3 days) was much lower than the MODIS sensor (1 day). BA estimations between the two products were very similar in 2019, although C3SBA10 had $0.28 \mathrm{Mkm}^{2}$ less BA (global BA: $3.63 \mathrm{Mkm}^{2}$ for C3SBA10 and $3.91 \mathrm{Mkm}^{2}$ for FireCCI51). Most of this difference (92\%) was found in tropical savanna, where a systematic underestimation of the C3SBA10 product was noticeable (Figure 9). This tendency towards underestimation was observed in other global BA products (generally based on coarse spatial resolution sensors) when comparing with regional products based on medium 
https://doi.org/10.5194/essd-2020-399

Preprint. Discussion started: 14 January 2021

(c) Author(s) 2021. CC BY 4.0 License.

\section{(c) (1)}

resolution sensors. For instance, a continental BA product at $20 \mathrm{~m}$ derived from Sentinel-2 (S2) for the year 2016 and SubSaharan Africa found that global BA products significantly underestimate total BA, as they included $80 \%$ less area than the S2 BA product (Roteta et al., 2019). This was mainly caused by the poor detection of small fires $(<250$ ha) in global products. C3SBA10 is likely missing more small fires than FireCCI51 due to its coarser spatial resolution (300 $\mathrm{m}$ vs $250 \mathrm{~m}$ ).

This tendency towards underestimation was confirmed by the validation exercise carried out through the overlapping threeyear period (2017-2019), which showed that both global BA products presented higher omission than commission errors. This trend agrees with the validation exercises of other global BA products that can be found in the literature (Boschetti et al., 2019;Chuvieco et al., 2018;Padilla et al., 2015) as well as with the abovementioned inability of moderate resolution BA products to detect small fire patches. The omission errors presented in this paper were lower than those found by previous authors, e.g. 72.6\% for the NASA's standard product in Boschetti et al. (2019) or $81 \%$ and $71 \%$ for two consecutive versions of FireCCI products (FireCCI41 and FireCCI50) in Chuvieco et al. (2018). However, it must be highlighted that these numbers are not fully comparable to those presented in this paper since all these studies used the so called short units (reference data generated from a maximum period of 16 days) instead of long units (reference data covering several months, as done in this study) to estimate the spatial accuracy of the products. The short units' approach is more affected by the temporal reporting accuracy (Section 3.2.2) of the global BA products than when using long units. A preliminary assessment of this effect was included in Lizundia-Loiola et al. (2020b) and in Franquesa et al. (2020b), showing a decrease of about 25\% in commission and 15\% in omission errors (in FireCCI51) for a validation sample of Sub-Saharan Africa 2016.

In any case, both the validation exercise and the consistency assessment showed a high agreement between the predecessor global BA product FireCCI51 and the operational C3SBA10. Although this consistency is still high in the years where only

500 S3A is available (2017-2018) it significantly increased in 2019 due to the availability of the second S3B satellite. In fact, in 2019 the C3SBA10 product showed a similar accuracy $(\mathrm{DC}=0.59 \pm 0.04)$ to that estimated for the FireCCI51 $(\mathrm{DC}=0.61 \pm 0.03$ ). The global and annual comparison metrics for that year were $\mathrm{r}=0.952$, slope $=0.88$ and $\mathrm{RMSE}=1.07$ $\mathrm{km}^{2}$ with a $0.05^{\circ}$ spatial resolution, the finest spatial resolution used in the comparison (Table 5). The agreement between the products improved as the comparison resolution decreased (Table 5, and Figure 8).

505 A deeper analysis of the year 2019 showed different trends in the consistency between products among the biomes. It was found that the changes in the correlation between products were linked to the BA detected for each month and biome. Although this relationship did not seem to be linear, i.e. a specific increase in BA did not mean a parallel increase in the correlation, it was clear that the larger the BA detected the higher the correlation between products. The tropical savanna was an obvious example, were most of global BA was found. The boreal regions were another example where the correlation is the highest in the months with the highest fire activity, while it significantly decreases for the rest of the months. The extreme wildfire event of Eastern Australia (Bowman et al., 2020) clearly showed this phenomenon since it significantly increased BA and agreement between products in December in the Mediterranean biome and in November and December in temperate forests. 
https://doi.org/10.5194/essd-2020-399

Preprint. Discussion started: 14 January 2021

(c) Author(s) 2021. CC BY 4.0 License.

There were some unusual cases as well, where higher BA did not necessarily mean higher correlation. This was the case of

the temperate areas where the correlation decreased in April. Temperate savanna and forest biomes encompass almost all the Northern Hemisphere mid-latitude croplands located in the Russian Federation and Kazakhstan (Hall et al., 2016). Cropland fires are characterised to be small and transient (McCarty et al., 2009;Randerson et al., 2012), which made moderate resolution BA products (250-500 m) unable to properly characterise the extent of cropland BA patches (Hall et al., 2016;Zhu et al., 2017). It is reasonable to assume that the same issue was affecting both the FireCCI51 and C3SBA10 products, which clearly increased the uncertainty in those regions and, hence, decreased the agreement. In fact, it was very likely that the rest of the biomes were affected by a similar issue (Vadrevu et al., 2019), showing a decrease in the agreement of products from March to May (Figure 8) when agricultural activity is high globally (Randerson et al., 2012).

The impact of agricultural fire activity in the performance of moderate BA products is only an example of the importance of the human factor in global fire regimes (Andela et al., 2017). Benali et al. (2017) assessed the existence of bimodal fire seasons, i.e. areas with two separate peak months, that were directly related to human activities. They found that about $25 \%$ of the areas with relevant fire activity showed this behaviour. In those cases, at least one of the two fire seasons was found to take place in sub-optimal weather conditions. Commonly, those periods have less valid images available due to clouds and cloud shadows, hindering BA detection, increasing uncertainty, and reducing agreement between products.

The sensor characteristics are also affecting the correlation between products as well. Different sensors imply different observation geometries, different angular effects and different times of overpass, directly influencing what is observed by each sensor. This led to the detection of different burned patches in one product compared to the other, e.g. in cropland areas, or to the detection of different regions of the same burned patch as in some xeric shrublands, were fires can be large, but also irregular and with high spread rates (Laurent et al., 2018). Conversely, the temporal reporting accuracy (Section 3.2.2) was not significantly affected by this issue since a similar accuracy was shown by both products through the studied three-year period (Figure 7). This was due to the use of monthly composites, which tend to select the most suitable observation from the images available and did not require statistics of several pre- and post-fire images as in the case of multitemporal approaches.

The results presented in this paper represent a first step in the transition from MODIS-based to S3-based BA products. In that sense, OLCI sensor have shown a good capacity to detect BA globally, although these estimations still depend on

540 MODIS active fires. Future work should be done to assess the impact of changing the source of the active fires to other sensors such as the Visible Infrared Imaging Radiometer Suite (VIIRS) on board Suomi-NPP and NOAA-20 or the Sea and Land Surface Temperature Radiometer (SLSTR) on board S3. In the former case, VIIRS active fires can considerably increase the detection of small fires due to its improved spatial resolution of 375m (Oliva and Schroeder, 2015; Schroeder et al., 2014), although the impact on the identification of burned patches should be studied, due to the limitations of the 545 moderate resolution reflectance data to detect small burned areas. In the latter case, a first study of S3 SLSTR active fire product has shown a good performance of this product over small fires (Xu et al., 2020), which provides a unique opportunity to develop a hybrid BA algorithm entirely based on S3. Therefore, global BA estimations may be improved in 
https://doi.org/10.5194/essd-2020-399

Preprint. Discussion started: 14 January 2021

(c) Author(s) 2021. CC BY 4.0 License.

(c) (i)

the future if the operational algorithm used to detect BA within the C3S is updated with new and/or improved versions provided through research projects, such as FireCCI.

\section{Data availability}

The C3SBA10 product presented in this paper includes two types of BA files: monthly full resolution continental tiles and monthly global grid files at an aggregated resolution of 0.25 degrees, as described in Section 2.4 and Table 2. Both datasets, pixel and grid data types, are freely available through the Copernicus Climate Data Store (CDS) repository (DOI: https://doi.org/10.24381/cds.f333cf85, Lizundia-Loiola et al. (2020a)), referenced as OLCI C3S Burned Area v1.0. Users should note that FireCCI51 is also available through the same DOI, referenced as MODIS FireCCI v5.1.1cds.

Additionally, the reference files generated to spatially validate the data presented in this publication has been released and are available at https://doi.org/10.21950/BBQQU7 (Franquesa et al., 2020a).

\section{Conclusions}

This paper presents a new global BA product, called C3SBA10, that was developed and produced within the Copernicus Climate Change Service. The last version of a series of global BA algorithms developed by the ESA's FireCCI project, known as FireCCI51 (Lizundia-Loiola et al., 2020b), was adapted to detect burned area for this Service. The algorithm follows a two-phase hybrid approach, which is based on S3 OLCI surface reflectance and MODIS active fires. Initially, the algorithm detects pixels with a high probability of being burned based on active fire information and NIR reflectance. Then, thresholds adapted to each fire and fuel conditions are computed using spatio-temporal active-fire clusters and their surroundings. Finally, a contextual growing is applied to fully detect the burned patch. Thus, the first step aims to reduce commission errors while the second reduces omission ones. This algorithm is being operationally applied to produce the C3SBA10 product, which is the official BA product of the C3S service. At the time of writing this paper more than three years (January 2017 - present) of global BA are publicly available at the Climate Data Store in pixel (300 m) and grid $\left(0.25^{\circ}\right)$ format. The C3SBA10 may be understood as a continuation of the FireCCI51 global BA product (Lizundia-Loiola et al., 2020b), which is available from 2001 to 2019. The spatial and temporal consistency assessment and the temporal reporting accuracy analysis showed a very high correlation between both products, mainly in 2019 when both S3A and B were available, ensuring an uninterrupted provision of global BA information from 2001 to present. 
https://doi.org/10.5194/essd-2020-399

Preprint. Discussion started: 14 January 2021

(c) Author(s) 2021. CC BY 4.0 License.

(c) (i)

\section{Appendix A: Supplementary tables}

\section{Author contributions}

JL, MLP and EC have written the first draft of the manuscript. JL has coordinated the manuscript production and developed the algorithm, prepared the figures, and made the intercomparison analysis. MF generated the reference data and validated the products. GK and MB were responsible of the pre-processing of the OLCI data and the production of the global burned area product. All the authors have contributed to the writing and reviewing of the manuscript and agreed on the final version.

\section{Competing interests}

The authors declare that they have no conflict of interest.

\section{Financial support}

This study has been funded by the Service Contract for the provision of land CDRs and ICDRs of the Copernicus Climate Change Service (contract no. ECMWF/COPERNICUS/2018/C3S_312b_Lot5_VITO/SC1), the ESA Climate Change Initiative - Fire ECV (contract no. 4000126706/19/I-NB), and the Spanish Ministry of Science, Innovation, and Universities through a FPU doctoral fellowship (FPU17/02438).

\section{References}

Aleksankina, K., Heal, M. R., Dore, A. J., Van Oijen, M., and Reis, S.: Global sensitivity and uncertainty analysis of an atmospheric chemistry transport model: the FRAME model (version 9.15.0) as a case study, Geosci. Model Dev., 11, 16531664, 10.5194/gmd-11-1653-2018, 2018.

590 Alonso-Canas, I., and Chuvieco, E.: Global Burned Area Mapping from ENVISAT-MERIS data Remote Sensing of Environment, 163, 140-152, http://dx.doi.org/10.1016/j.rse.2015.03.011, 2015.

Arctic wildfires: How bad are they and what caused them?: https://www.bbc.com/news/world-europe-49125391, 2019.

Andela, N., and van der Werf, G. R.: Recent trends in African fires driven by cropland expansion and El Niño to La Niña transition, Nature Climate Change, 4, 791-795, 10.1038/nclimate2313, 2014.

595 Andela, N., Morton, D. C., Giglio, L., Chen, Y., van der Werf, G. R., Kasibhatla, P. S., DeFries, R. S., Collatz, G. J., Hantson, S., Kloster, S., Bachelet, D., Forrest, M., Lasslop, G., Li, F., Mangeon, S., Melton, J. R., Yue, C., and Randerson, J. T.: A human-driven decline in global burned area, Science, 356, 1356, 10.1126/science.aal4108, 2017.

Bastarrika, A., Alvarado, M., Artano, K., Martinez, M., Mesanza, A., Torre, L., Ramo, R., and Chuvieco, E.: BAMS: A Tool for Supervised Burned Area Mapping Using Landsat Data, Remote Sensing, 6, 12360-12380, 2014. 
https://doi.org/10.5194/essd-2020-399

Preprint. Discussion started: 14 January 2021

(c) Author(s) 2021. CC BY 4.0 License.

600 Benali, A., Mota, B., Carvalhais, N., Oom, D., Miller, L. M., Campagnolo, M. L., and Pereira, J. M. C.: Bimodal fire regimes unveil a global-scale anthropogenic fingerprint, Global Ecology and Biogeography, 26, 799-811, 2017.

Bistinas, I., Oom, D., Sá, A. C. L., Harrison, S. P., Prentice, I. C., and Pereira, J. M. C.: Relationships between human population density and burned area at continental and global scales, PLoS One, 8, e81188-e81188, 10.1371/journal.pone.0081188, 2013.

605 Bojinski, S., Verstraete, M., Peterson, T. C., Richter, C., Simmons, A., and Zemp, M.: The concept of essential climate variables in support of climate research, applications, and policy, Bulletin of the American Meteorological Society, 95, 1431-1443, DOI:10.1175/BAMS-D-13-00047.1, 2014.

Boschetti, L., Eva, H. D., Brivio, P. A., and Gregoire, J. M.: Lessons to be learned from the comparison of three satellitederived biomass burning products, Geophysical Research Letters, 31, L21501, doi:21510.21029/22004GL021229, 2004.

610 Boschetti, L., Roy, D. P., Justice, C. O., and Giglio, L.: Global assessment of the temporal reporting accuracy and precision of the MODIS burned area product, International Journal of Wildland Fire, 19, 705-709, 2010.

Boschetti, L., Roy, D. P., Giglio, L., Huang, H., Zubkova, M., and Humber, M. L.: Global validation of the collection 6 MODIS burned area product, Remote Sensing of Environment, 235, 111490, https://doi.org/10.1016/j.rse.2019.111490, 2019.

615 Bowman, D., Williamson, G., Yebra, M., Lizundia-Loiola, J., Pettinari, M. L., Shah, S., Bradstock, R., and Chuvieco, E.: Wildfires: Australia needs national monitoring agency, Nature, 584, 188-191, 2020.

Bowman, D. M. J. S., Balch, J. K., Artaxo, P., Bond, W. J., Carlson, J. M., Cochrane, M. A., D’Antonio, C. M., DeFries, R. S., Doyle, J. C., Harrison, S. P., Johnston, F. H., Keeley, J. E., Krawchuk, M. A., Kull, C. A., Marston, J. B., Moritz, M. A., Prentice, I. C., Roos, C., Scott, A., Swetnam, T., Van der Werf, G., and Pyne, S. J.: Fire in the Earth system, Science, 324, $620481-484,2009$.

Chen, Y., Morton, D. C., Jin, Y., Collatz, G. J., Kasibhatla, P. S., van der Werf, G. R., DeFries, R. S., and Randerson, J. T.: Long-term trends and interannual variability of forest, savanna and agricultural fires in South America, Carbon Management, 4, 617-638, 10.4155/cmt.13.61, 2013.

Chuvieco, E., Yue, C., Heil, A., Mouillot, F., Alonso-Canas, I., Padilla, M., Pereira, J. M., Oom, D., and Tansey, K.: A new 625 global burned area product for climate assessment of fire impacts, Global Ecology and Biogeography, 25, 619-629, 10.1111/geb.12440, 2016.

Chuvieco, E., Pettinari, M. L., Heil, A., and Storm, T.: ESA CCI EVC Fire Disturbance: D1.2 Product Specification Document, version 6.3, 2017.

Chuvieco, E., Lizundia-Loiola, J., Pettinari, M. L., Ramo, R., Padilla, M., Tansey, K., Mouillot, F., Laurent, P., Storm, T., 630 and Heil, A.: Generation and analysis of a new global burned area product based on MODIS $250 \mathrm{~m}$ reflectance bands and thermal anomalies, Earth System Science Data, 10, 2015-2031, 2018.

Chuvieco, E., Mouillot, F., van der Werf, G. R., San Miguel, J., Tanasse, M., Koutsias, N., García, M., Yebra, M., Padilla, M., Gitas, I., Heil, A., Hawbaker, T. J., and Giglio, L.: Historical background and current developments for mapping burned 
https://doi.org/10.5194/essd-2020-399

Preprint. Discussion started: 14 January 2021

(c) Author(s) 2021. CC BY 4.0 License.

(c) (i)

area from satellite Earth observation, Remote Sensing of Environment, 225, 45-64, https://doi.org/10.1016/j.rse.2019.02.013,

635

2019.

Cohen, W. B., Yang, Z., and Kennedy, R.: Detecting trends in forest disturbance and recovery using yearly Landsat time series: 2. TimeSync - Tools for calibration and validation, Remote Sensing of Environment, 114, 2911-2924, http://dx.doi.org/10.1016/j.rse.2010.07.010, 2010.

Congalton, R. G.: A review of assessing the accuracy of classifications of remotely sensed data, Remote Sensing of

Daniau, A.-L., Sánchez Goñi, M. F., Martinez, P., Urrego, D. H., Bout-Roumazeilles, V., Desprat, S., and Marlon, J. R.: Orbital-scale climate forcing of grassland burning in southern Africa, Proceedings of the National Academy of Sciences, 110, 5069, 10.1073/pnas.1214292110, 2013.

Defourny, P., Flasse, C., and Lamarche, C.: Product quality assessment report - ICDR Land Cover 2016 -2018. D2.3.12-

Dice, L. R.: Measures of the Amount of Ecologic Association Between Species, Ecology, 26, 297-302, 10.2307/1932409, 1945 .

Dinerstein, E., Olson, D., Joshi, A., Vynne, C., Burgess, N. D., Wikramanayake, E., Hahn, N., Palminteri, S., Hedao, P., Noss, R., Hansen, M., Locke, H., Ellis, E. C., Jones, B., Barber, C. V., Hayes, R., Kormos, C., Martin, V., Crist, E., Sechre st, 650 W., Price, L., Baillie, J. E. M., Weeden, D., Suckling, K., Davis, C., Sizer, N., Moore, R., Thau, D., Birch, T., Potapov, P., Turubanova, S., Tyukavina, A., de Souza, N., Pintea, L., Brito, J. C., Llewellyn, O. A., Miller, A. G., Patzelt, A., Ghazanfar, S. A., Timberlake, J., Klöser, H., Shennan-Farpón, Y., Kindt, R., Lillesø, J.-P. B., van Breugel, P., Graudal, L., Voge, M., Al-Shammari, K. F., and Saleem, M.: An Ecoregion-Based Approach to Protecting Half the Terrestrial Realm, BioScience, 67, 534-545, 10.1093/biosci/bix014, 2017.

655 Enright, N. J., Fontaine, J. B., Bowman, D. M. J. S., Bradstock, R. A., and Williams, R. J.: Interval squeeze: altered fire regimes and demographic responses interact to threaten woody species persistence as climate changes, Frontiers in Ecology and the Environment, 13, 265-272, 10.1890/140231, 2015.

ESA: Land Cover CCI Product User Guide Version 2. Tech. Rep., 2017.

Evangeliou, N., Kylling, A., Eckhardt, S., Myroniuk, V., Stebel, K., Paugam, R., Zibtsev, S., and Stohl, A.: Open fires in

660 Greenland in summer 2017: transport, deposition and radiative effects of BC, OC and BrC emissions, 2019.

Forkel, M., Dorigo, W., Lasslop, G., Teubner, I., Chuvieco, E., and Thonicke, K.: A data-driven approach to identify controls on global fire activity from satellite and climate observations (SOFIA V1), Geoscientific Model Development, 10, 4443, 2017.

Forkel, M., Andela, N., Harrison, S. P., Lasslop, G., van Marle, M., Chuvieco, E., Dorigo, W., Forrest, M., Hantson, S., Heil,

665 A., Li, F., Melton, J., Sitch, S., Yue, C., and Arneth, A.: Emergent relationships with respect to burned area in global satellite observations and fire-enabled vegetation models, Biogeosciences, 16, 57-76, 10.5194/bg-16-57-2019, 2019. 
https://doi.org/10.5194/essd-2020-399

Preprint. Discussion started: 14 January 2021

(c) Author(s) 2021. CC BY 4.0 License.

(c) (i)

Franquesa, M., Vanderhoof, M. K., Stavrakoudis, D., Gitas, I., Roteta, E., Padilla, M., and Chuvieco, E.: BARD: a global and regional validation burned area database, V5, e-cienciaDatos, https://doi.org/10.21950/BBQQU7, 2020a.

Franquesa, M., Vanderhoof, M. K., Stavrakoudis, D., Gitas, I. Z., Roteta, E., Padilla, M., and Chuvieco, E.: Development of 670 a standard database of reference sites for validating global burned area products, Earth Syst. Sci. Data, 12, 3229-3246, 10.5194/essd-12-3229-2020, 2020b.

Friedlingstein, P., O'Sullivan, M., Jones, M. W., Andrew, R. M., Hauck, J., Olsen, A., Peters, G. P., Peters, W., Pongratz, J., Sitch, S., Le Quéré, C., Canadell, J. G., Ciais, P., Jackson, R. B., Alin, S., Aragão, L. E. O. C., Arneth, A., Arora, V., Bates, N. R., Becker, M., Benoit-Cattin, A., Bittig, H. C., Bopp, L., Bultan, S., Chandra, N., Chevallier, F., Chini, L. P., Evans, W., 675 Florentie, L., Forster, P. M., Gasser, T., Gehlen, M., Gilfillan, D., Gkritzalis, T., Gregor, L., Gruber, N., Harris, I., Hartung, K., Haverd, V., Houghton, R. A., Ilyina, T., Jain, A. K., Joetzjer, E., Kadono, K., Kato, E., Kitidis, V., Korsbakken, J. I., Landschützer, P., Lefèvre, N., Lenton, A., Lienert, S., Liu, Z., Lombardozzi, D., Marland, G., Metzl, N., Munro, D. R., Nabel, J. E. M. S., Nakaoka, S. I., Niwa, Y., O'Brien, K., Ono, T., Palmer, P. I., Pierrot, D., Poulter, B., Resplandy, L., Robertson, E., Rödenbeck, C., Schwinger, J., Séférian, R., Skjelvan, I., Smith, A. J. P., Sutton, A. J., Tanhua, T., Tans, P. P.,

680 Tian, H., Tilbrook, B., van der Werf, G., Vuichard, N., Walker, A. P., Wanninkhof, R., Watson, A. J., Willis, D., Wiltshire, A. J., Yuan, W., Yue, X., and Zaehle, S.: Global Carbon Budget 2020, Earth Syst. Sci. Data, 12, 3269-3340, 10.5194/essd12-3269-2020, 2020.

Gallego, F. J.: Stratified sampling of satellite images with a systematic grid of points, ISPRS Journal of Photogrammetry and Remote Sensing, 59, 369-376, https://doi.org/10.1016/j.isprsjprs.2005.10.001, 2005.

GCOS: The Global Observing System for Climate: Implementation Needs. GCOS-200, World Meteorological Organization, Geneva, Switzerland, 2016.

Giglio, L., Randerson, J. T., van der Werf, G. R., Kasibhatla, P. S., Collatz, G. J., Morton, D. C., and DeFries, R. S.: Assessing variability and long-term trends in burned area by merging multiple satellite fire products, Biogeosciences Discuss., 7, 1171-1186, doi:1110.5194/bg-1177-1171-2010,, 2010.

690 Giglio, L., Boschetti, L., Roy, D. P., Humber, M. L., and Justice, C. O.: The Collection 6 MODIS burned area mapping algorithm and product, Remote Sensing of Environment, 217, 72-85, 2018a.

Giglio, L., Schroeder, W., Hall, J. V., and Justice, C. O.: Modis collection 6 active fire product user's guide revision B, Department of Geographical Sciences. University of Maryland, 2018b.

GlobAlbedo, C.: GlobAlbedo Algorithm Theoretical Basis Document Version 4.12, v4.12, 2013.

695 Hall, J. V., Loboda, T. V., Giglio, L., and McCarty, G. W.: A MODIS-based burned area assessment for Russian croplands: Mapping requirements and challenges, Remote Sensing of Environment, 184, 506-521, https://doi.org/10.1016/j.rse.2016.07.022, 2016.

Hantson, S., Arneth, A., Harrison, S. P., Kelley, D. I., Prentice, I. C., Rabin, S. S., Archibald, S., Mouillot, F., Arnold, S. R., and Artaxo, P.: The status and challenge of global fire modelling, Biogeosciences, 13, 3359-3375, 2016. 
https://doi.org/10.5194/essd-2020-399

Preprint. Discussion started: 14 January 2021

(c) Author(s) 2021. CC BY 4.0 License.

Hantson, S., Kelley, D. I., Arneth, A., Harrison, S. P., Archibald, S., Bachelet, D., Forrest, M., Hickler, T., Lasslop, G., Li, F., Mangeon, S., Melton, J. R., Nieradzik, L., Rabin, S. S., Prentice, I. C., Sheehan, T., Sitch, S., Teckentrup, L., Voulgarakis, A., and Yue, C.: Quantitative assessment of fire and vegetation properties in simulations with fire-enabled vegetation models from the Fire Model Intercomparison Project, Geosci. Model Dev., 13, 3299-3318, 10.5194/gmd-133299-2020, 2020.

705 Heil, A.: ESA Climate Change Initiative - Fire_cci D1.1 User Requirements Document (URD), version 6.0, 2019.

Hu, L., Keller, C. A., Long, M. S., Sherwen, T., Auer, B., Da Silva, A., Nielsen, J. E., Pawson, S., Thompson, M. A., and Trayanov, A. L.: Global simulation of tropospheric chemistry at $12.5 \mathrm{~km}$ resolution: performance and evaluation of the GEOS-Chem chemical module (v10-1) within the NASA GEOS Earth system model (GEOS-5 ESM), Geoscientific Model Development, 4603-4620, 2018.

710 Humber, M. L., Boschetti, L., Giglio, L., and Justice, C. O.: Spatial and temporal intercomparison of four global burned area products, International Journal of Digital Earth, 1-25, 2018.

Kaiser, J., Heil, A., Andreae, M., Benedetti, A., Chubarova, N., Jones, L., Morcrette, J.-J., Razinger, M., Schultz, M., and Suttie, M.: Biomass burning emissions estimated with a global fire assimilation system based on observed fire radiative power, Biogeosciences, 9, 527-554, 2012.

715 Kelly, L. T., and Brotons, L.: Using fire to promote biodiversity, Science, 355, 1264, 10.1126/science.aam7672, 2017.

Kennedy, R. E., Yang, Z., and Cohen, W. B.: Detecting trends in forest disturbance and recovery using yearly Landsat time series: 1. LandTrendr - Temporal segmentation algorithms, Remote Sensing of Environment, 114, 2897-2910, http://dx.doi.org/10.1016/j.rse.2010.07.008, 2010.

Knorr, W., Kaminski, T., Arneth, A., and Weber, U.: Impact of human population density on fire frequency at the global

720 scale, Biogeosciences, 11, 1085-1102, 2014.

Kuenen, J. J. P., Visschedijk, A. J. H., Jozwicka, M., and Denier van der Gon, H. A. C.: TNO-MACC_II emission inventory; a multi-year (2003\&ndash;2009) consistent high-resolution European emission inventory for air quality modelling, Atmos. Chem. Phys., 14, 10963-10976, 10.5194/acp-14-10963-2014, 2014.

Laurent, P., Mouillot, F., Yue, C., Ciais, P., Moreno, M. V., and Nogueira, J. M.: FRY, a global database of fire patch 725 functional traits derived from space-borne burned area products, Scientific data, 5, 180132, 2018.

Lizundia-Loiola, J., Franquesa, M., Boettcher, M., Kirches, G., Pettinari, M. L., and Chuvieco, E.: C3SBA10: OLCI C3S Burned Area v1.0, Climate Data Store, https://doi.org/10.24381/cds.f333cf85, 2020a.

Lizundia-Loiola, J., Otón, G., Ramo, R., and Chuvieco, E.: A spatio-temporal active-fire clustering approach for global burned area mapping at $250 \mathrm{~m}$ from MODIS data, Remote Sensing of Environment, 236, 111493, 2020b.

730 Marlon, J. R., Bartlein, P. J., Daniau, A.-L., Harrison, S. P., Maezumi, S. Y., Power, M. J., Tinner, W., and Vanniére, B.: Global biomass burning: a synthesis and review of Holocene paleofire records and their controls, Quaternary Science Reviews, 65, 5-25, 2013. 
https://doi.org/10.5194/essd-2020-399

Preprint. Discussion started: 14 January 2021

(c) Author(s) 2021. CC BY 4.0 License.

(c) (i)

McCarty, J. L., Korontzi, S., Justice, C. O., and Loboda, T.: The spatial and temporal distribution of crop residue burning in the contiguous United States, Science of The Total Environment, 407, 5701-5712,

735 https://doi.org/10.1016/j.scitotenv.2009.07.009, 2009.

Merchant, C. J., Paul, F., Popp, T., Ablain, M., Bontemps, S., Defourny, P., Hollmann, R., Lavergne, T., Laeng, A., and de Leeuw, G.: Uncertainty information in climate data records from Earth observation, Earth System Science Data, 9, 2017.

Mittaz, J., Merchant, C. J., and Woolliams, E. R.: Applying principles of metrology to historical Earth observations from satellites, Metrologia, 56, 032002, 2019.

740 Morisette, J. T., Baret, F., and Liang, S.: Special issue on global land product validation, IEEE Transactions on Geoscience and Remote Sensing, 44, 1695-1697, 2006.

Moritz, M. A., Parisien, M.-A., Batllori, E., Krawchuk, M. A., Van Dorn, J., Ganz, D. J., and Hayhoe, K.: Climate change and disruptions to global fire activity, Ecosphere, 3, art49, 10.1890/es11-00345.1, 2012.

Mouillot, F., Schultz, M. G., Yue, C., Cadule, P., Tansey, K., Ciais, P., and Chuvieco, E.: Ten years of global burned area products from spaceborne remote sensing-A review: Analysis of user needs and recommendations for future developments, International Journal of Applied Earth Observation and Geoinformation, 26, 64-79, 2014.

Oliva, P., Martin, P., and Chuvieco, E.: Burned area mapping with MERIS post-fire image, International Journal of Remote Sensing, 32, 4175-4201, 10.1080/01431161.2010.489062, 2011.

Oliva, P., and Schroeder, W.: Assessment of VIIRS 375m active fire detection product for direct burned area mapping,

Remote Sensing of Environment, 160, 144-155, https://doi.org/10.1016/j.rse.2015.01.010, 2015.

Padilla, M., Stehman, S. V., and Chuvieco, E.: Validation of the 2008 MODIS-MCD45 global burned area product using stratified random sampling, Remote Sensing of Environment 144, 187-196, http://dx.doi.org/10.1016/j.rse.2014.01.008, 2014.

Padilla, M., Stehman, S. V., Hantson, S., Oliva, P., Alonso-Canas, I., Bradley, A., Tansey, K., Mota, B., Pereira, J. M., and Chuvieco, E.: Comparing the Accuracies of Remote Sensing Global Burned Area Products using Stratified Random Sampling and Estimation, Remote Sensing of Environment 160, 114-121, http://dx.doi.org/10.1016/j.rse.2014.01.008, 2015. Padilla, M., Olofsson, P., Stehman, S. V., Tansey, K., and Chuvieco, E.: Stratification and sample allocation for reference burned area data, Remote Sensing of Environment, 203, 240-255, 2017.

Pastor-Guzman, J., Brown, L., Morris, H., Bourg, L., Goryl, P., Dransfeld, S., and Dash, J.: The Sentinel-3 OLCI Terrestrial Chlorophyll Index (OTCI): Algorithm Improvements, Spatiotemporal Consistency and Continuity with the MERIS Archive, Remote Sensing, 12, 10.3390/rs12162652, 2020.

Plummer, S., Lecomte, P., and Doherty, M.: The ESA Climate Change Initiative (CCI): A European contribution to the generation of the Global Climate Observing System, Remote Sensing of Environment, 203, 2-8, https://doi.org/10.1016/j.rse.2017.07.014, 2017. 
https://doi.org/10.5194/essd-2020-399

Preprint. Discussion started: 14 January 2021

(c) Author(s) 2021. CC BY 4.0 License.

765 Poulter, B., Cadule, P., Cheiney, A., Ciais, P., Hodson, E., Peylin, P., Plummer, S., Spessa, A., Saatchi, S., and Yue, C.: Sensitivity of global terrestrial carbon cycle dynamics to variability in satellite-observed burned area, Global Biogeochemical Cycles, 29, 207-222, 2015.

Randerson, J., Chen, Y., Werf, G., Rogers, B., and Morton, D.: Global burned area and biomass burning emissions from small fires, Journal of Geophysical Research: Biogeosciences (2005-2012), 117 - G04012, 1-23, 10.1029/2012JG002128, 2012.

Roteta, E., Bastarrika, A., Padilla, M., Storm, T., and Chuvieco, E.: Development of a Sentinel-2 burned area algorithm: Generation of a small fire database for sub-Saharan Africa, Remote Sensing of Environment, 222, 1-17, 2019.

Roy, D. P., Boschetti, L., and Justice, C. O.: The collection 5 MODIS burned area product - Global evaluation by comparison with the MODIS active fire product, Remote Sensing of Environment, 112, 3690-3707, 2008.

775 Sayer, A. M., Govaerts, Y., Kolmonen, P., Lipponen, A., Luffarelli, M., Mielonen, T., Patadia, F., Popp, T., Povey, A. C., and Stebel, K.: A review and framework for the evaluation of pixel-level uncertainty estimates in satellite aerosol remote sensing, Atmos. Meas. Tech. Discuss, 2019.

Schroeder, W., Oliva, P., Giglio, L., and Csiszar, I. A. J. R. S. o. E.: The New VIIRS $375 \mathrm{~m}$ active fire detection data product: Algorithm description and initial assessment, 143, 85-96, 2014.

780 Seiler, W., and Crutzen, P. J.: Estimates of gross and net fluxes of carbon between the biosphere and the atmosphere from biomass burning, Climatic Change, 2, 207-247, 1980.

Thépaut, J., Dee, D., Engelen, R., and Pinty, B.: The Copernicus Programme and its Climate Change Service, IGARSS 2018 - 2018 IEEE International Geoscience and Remote Sensing Symposium, 2018, 1591-1593,

Tosca, M. G., Randerson, J. T., Zender, C. S., Flanner, M. G., and Rasch, P. J.: Do biomass burning aerosols intensify 785 drought in equatorial Asia during El Niño?, Atmospheric Chemistry and Physics, 10, 3515-3528, 2010.

Tosca, M. G., Diner, D. J., Garay, M. J., and Kalashnikova, O. V.: Observational evidence of fire-driven reduction of cloud fraction in tropical Africa, Journal of Geophysical Research: Atmospheres, 119, 8418-8432, 2014.

Turco, M., Herrera, S., Tourigny, E., Chuvieco, E., and Provenzale, A.: A comparison of remotely-sensed and inventory datasets for burned area in Mediterranean Europe, International Journal of Applied Earth Observation and Geoinformation,

790 82, 101887, 2019a.

Turco, M., Jerez, S., Augusto, S., Tarín-Carrasco, P., Ratola, N., Jiménez-Guerrero, P., and Trigo, R. M.: Climate drivers of the 2017 devastating fires in Portugal, Scientific Reports, 9, 13886, 10.1038/s41598-019-50281-2, 2019b.

Vadrevu, K. P., Lasko, K., Giglio, L., Schroeder, W., Biswas, S., and Justice, C.: Trends in Vegetation fires in South and Southeast Asian Countries, Scientific Reports, 9, 7422, 10.1038/s41598-019-43940-x, 2019.

795 van der Werf, G. R., Dempewolf, J., Trigg, S. N., Randerson, J. T., Kasibhatla, P. S., Giglio, L., Murdiyarso, D., Peters, W., Morton, D. C., Collatz, G. J., Dolman, A. J., and DeFries, R. S.: Climate regulation of fire emissions and deforestation in equatorial Asia, Proceedings of the National Academy of Sciences, 105, 20350, 10.1073/pnas.0803375105, 2008. 
https://doi.org/10.5194/essd-2020-399

Preprint. Discussion started: 14 January 2021

(c) Author(s) 2021. CC BY 4.0 License.

(c) (1)

van der Werf, G. R., Randerson, J. T., Giglio, L., Collatz, G., Mu, M., Kasibhatla, P. S., Morton, D. C., DeFries, R. S., Jin, Y., and van Leeuwen, T. T.: Global fire emissions and the contribution of deforestation, savanna, forest, agricultural, and peat fires (1997-2009), Atmospheric Chemistry and Physics, 10, 11707-11735, doi:10.5194/acp-10-11707-2010, 2010.

van der Werf, G. R., Randerson, J. T., Giglio, L., Van Leeuwen, T. T., Chen, Y., Rogers, B. M., Mu, M., Van Marle, M. J. E., Morton, D. C., and Collatz, G. J.: Global fire emissions estimates during 1997-2016, Earth System Science Data, 9, 697$720,2017$.

Ward, D., Kloster, S., Mahowald, N., Rogers, B., Randerson, J., and Hess, P.: The changing radiative forcing of fires: global model estimates for past, present and future, Atmospheric Chemistry and Physics, 12, 2012.

Xu, W., Wooster, M. J., He, J., and Zhang, T.: First study of Sentinel-3 SLSTR active fire detection and FRP retrieval: Night-time algorithm enhancements and global intercomparison to MODIS and VIIRS AF products, Remote Sensing of Environment, 248, 111947, 2020.

Yue, C., Ciais, P., Houghton, R. A., and Nassikas, A. A.: Contribution of land use to the interannual variability of the land carbon cycle, Nature Communications, 11, 3170, 10.1038/s41467-020-16953-8, 2020.

Zhang, Z., Zhao, L., and Lin, A.: Evaluating the performance of Sentinel-3A OLCI land products for gross primary productivity estimation using ameriflux data, Remote Sensing, 12, 1927, 2020.

Zhu, C., Kobayashi, H., Kanaya, Y., and Saito, M.: Size-dependent validation of MODIS MCD64A1 burned area over six vegetation types in boreal Eurasia: Large underestimation in croplands, Scientific Reports, 7, 4181, 10.1038/s41598-017-

$815 \quad 03739-0,2017$. 
https://doi.org/10.5194/essd-2020-399

Preprint. Discussion started: 14 January 2021

(c) Author(s) 2021. CC BY 4.0 License.

(c) (1)

Figures

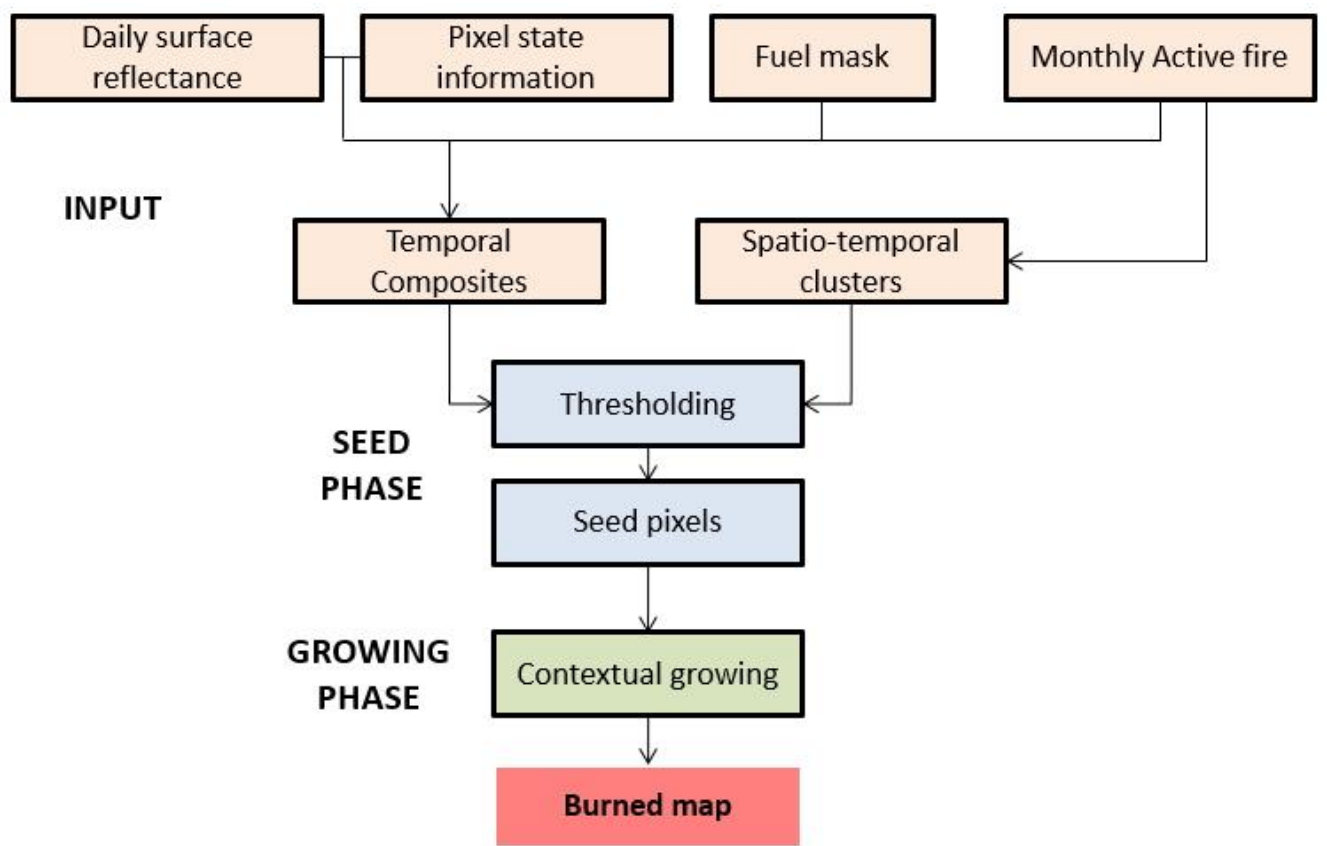

830 Figure 1. Simplified version of the main scheme of the global BA algorithm. Adapted from Lizundia-Loiola et al. (2020b).

$\mathrm{H}$

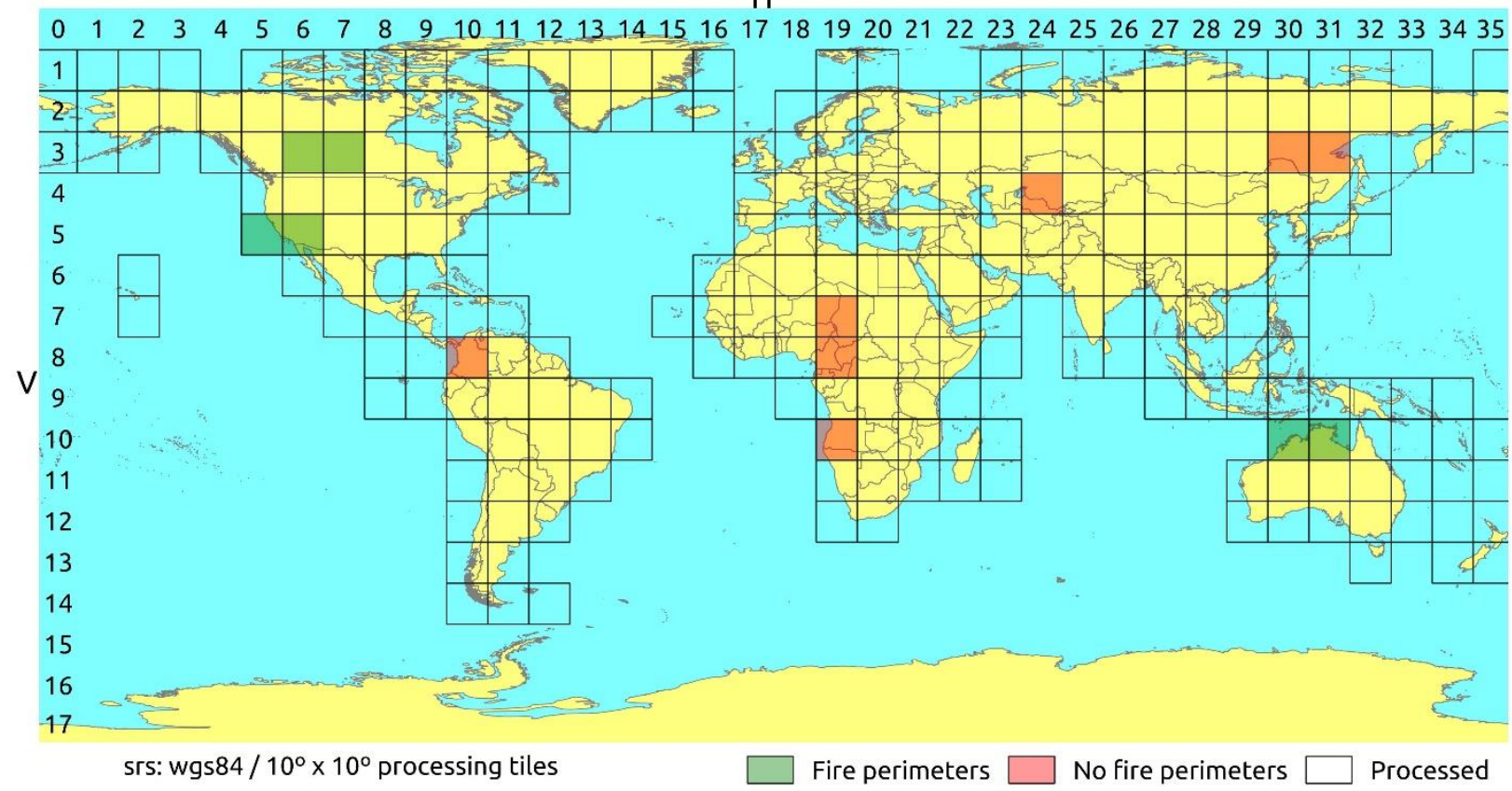

Figure 2. The 10x10 degree tiles used for the processing of the operational OLCI global BA product. A total of 273 tiles were processed, of which 13 were used to adapt the algorithm (red and green tiles). 
https://doi.org/10.5194/essd-2020-399

Preprint. Discussion started: 14 January 2021

(c) Author(s) 2021. CC BY 4.0 License.

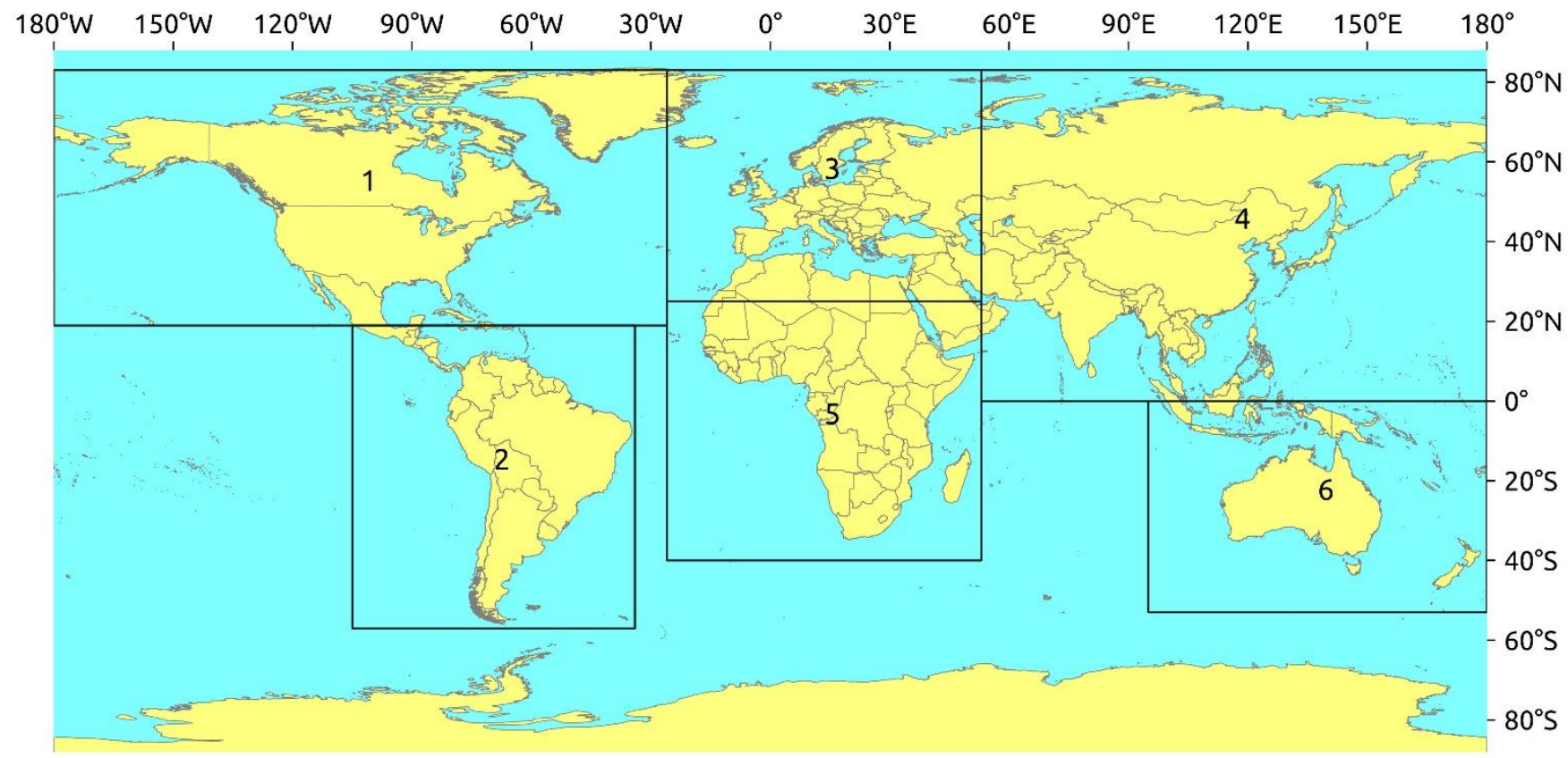

Figure 3. Continental tiles of the global BA pixel product. 
https://doi.org/10.5194/essd-2020-399

Preprint. Discussion started: 14 January 2021

(c) Author(s) 2021. CC BY 4.0 License.

(c) (1)

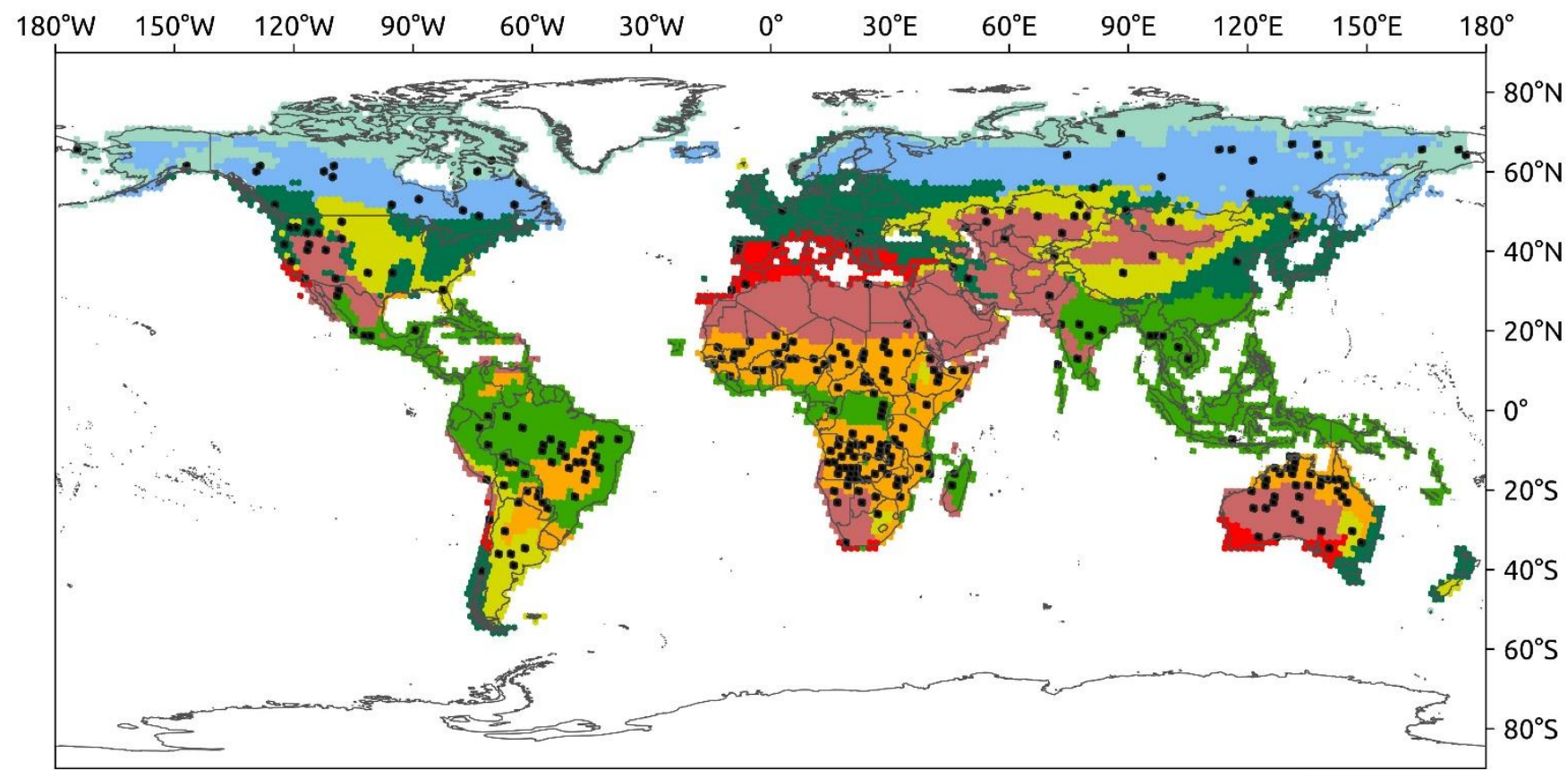

Deserts and xeric shrublands

Tropical forests
Temperate forests

Boreal forests

\section{Tropical savanna \\ Temperate savanna}

Mediterranean

Tundra

Figure 4. Biomes representing the first stratum of the validation sampling. The black locations show the 300 validation sites that were selected for 2017, 2018, and 2019 (100 for each year). 


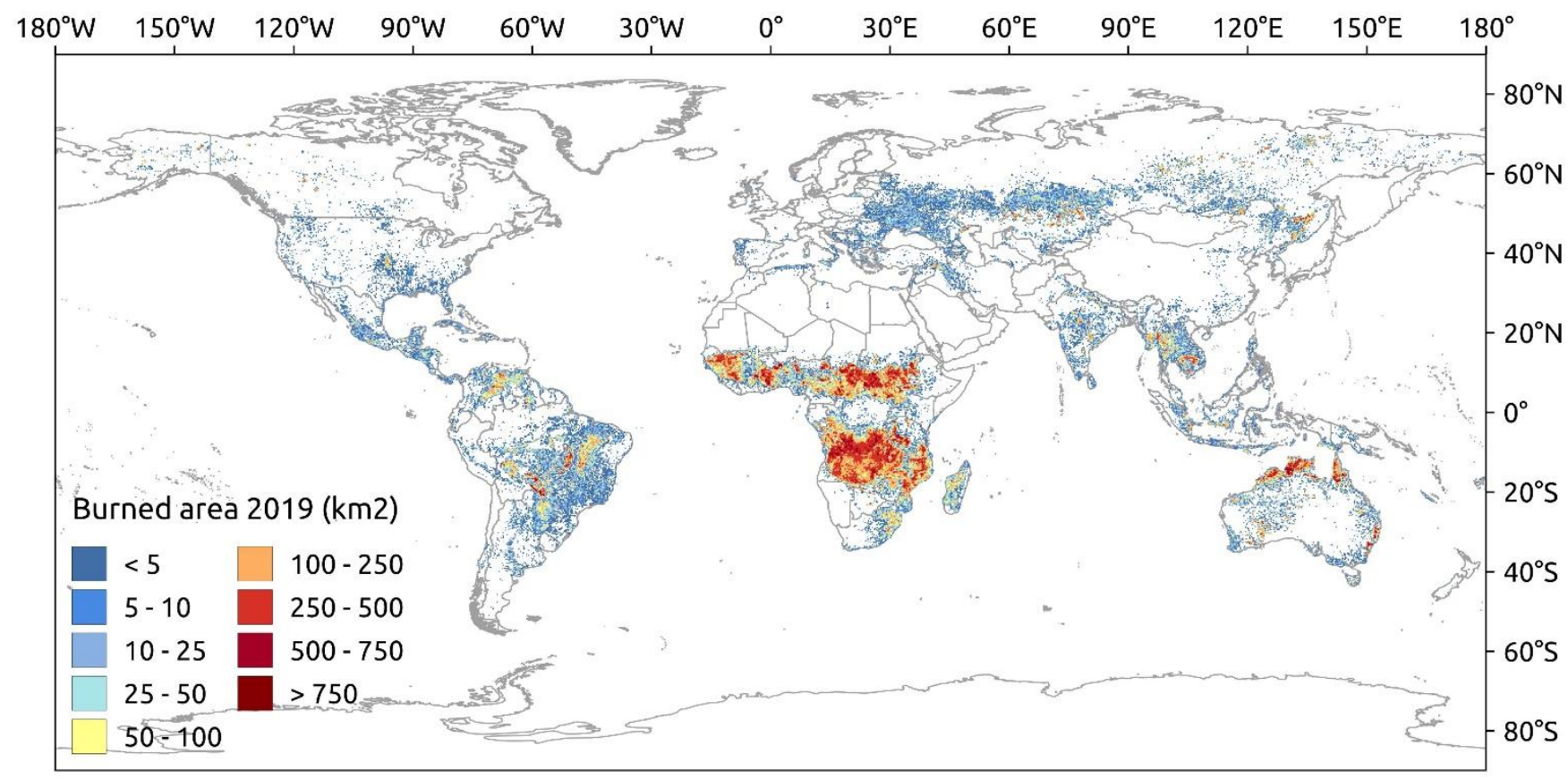

Figure 5. C3SBA10 annual accumulated BA for the year 2019 at $0.25^{\circ}$ spatial resolution.

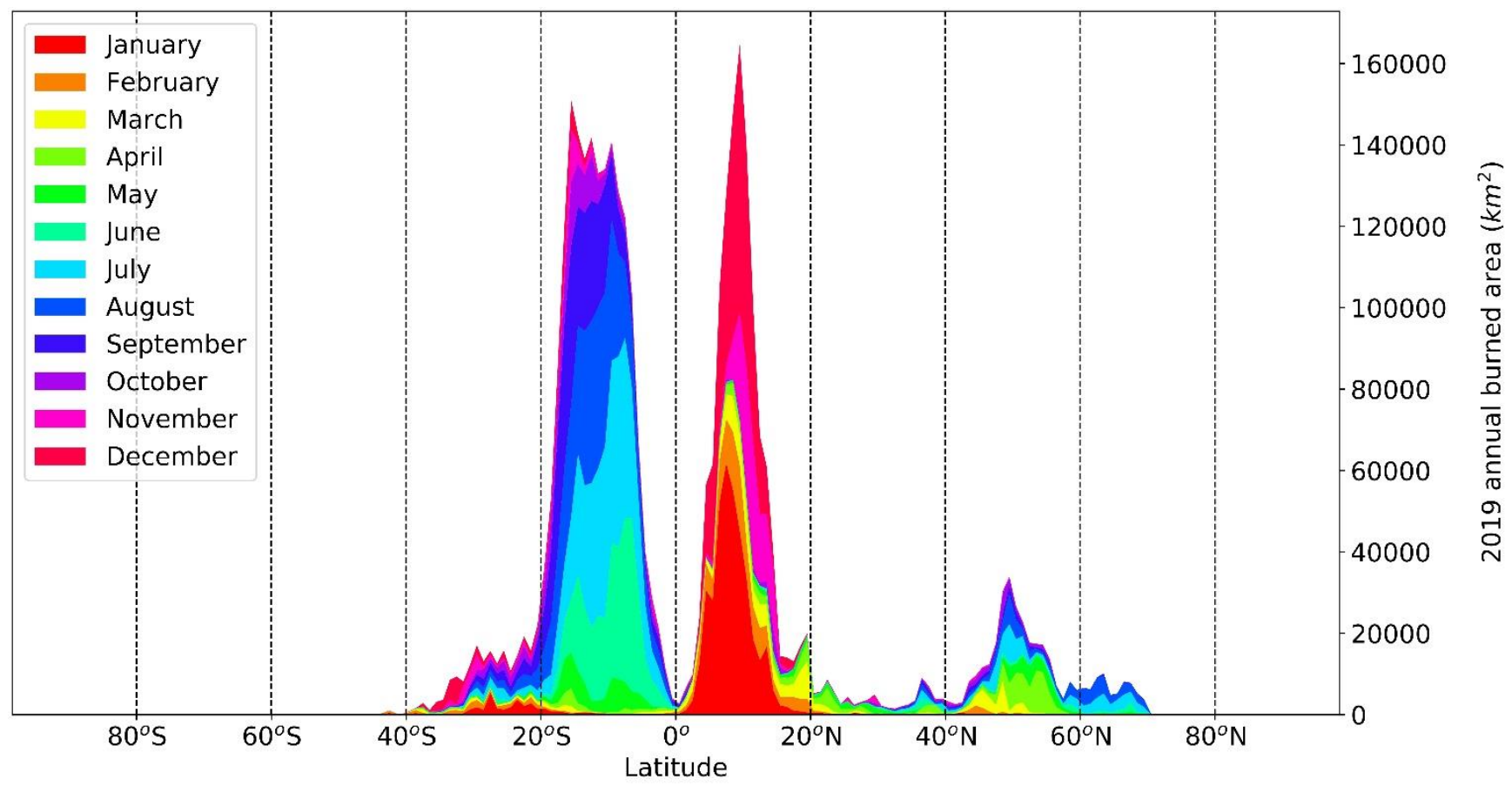

Figure 6. Monthly burned area for 2019 distributed along latitudes determined by C3SBA10. 

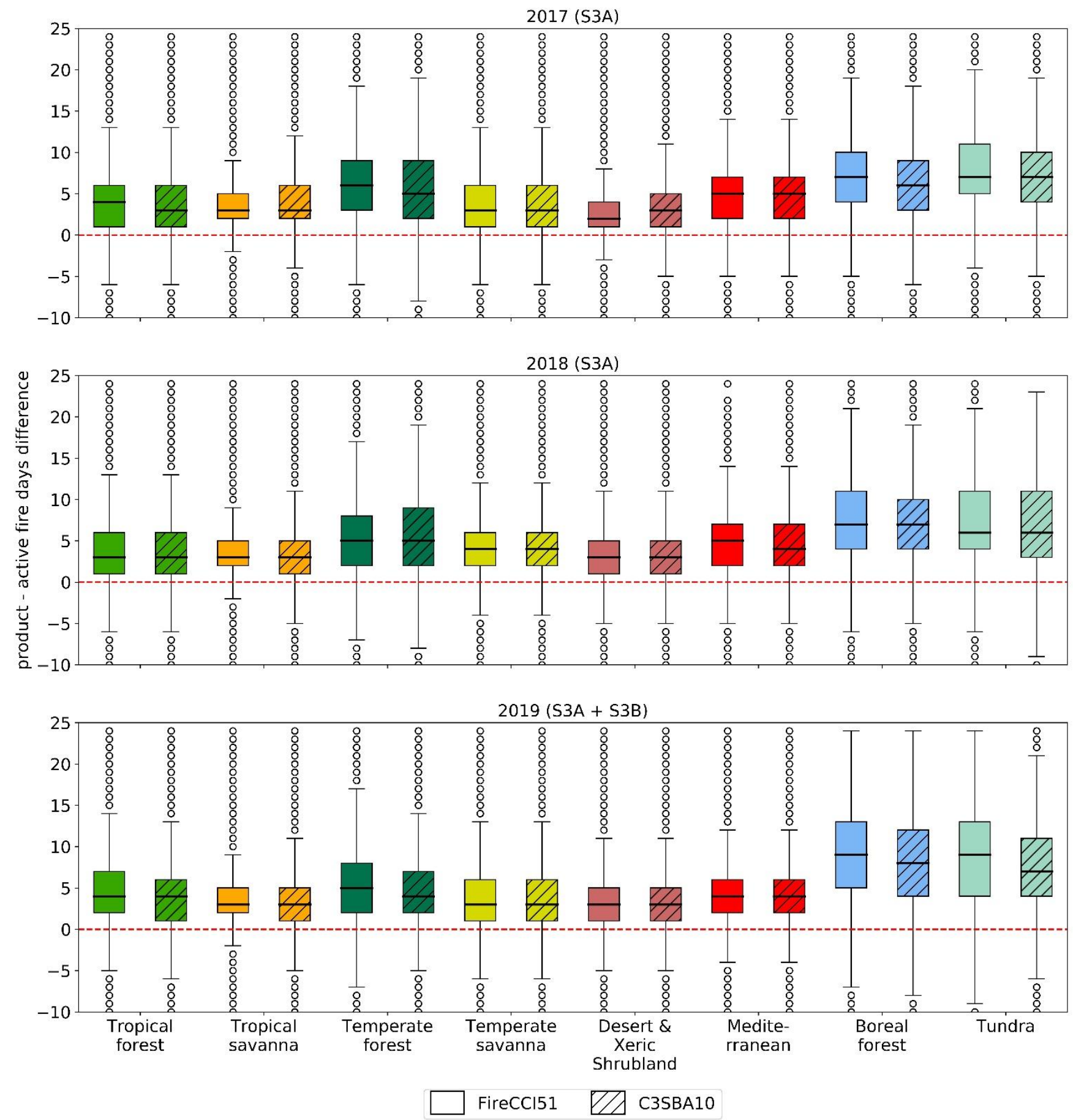

Figure 7. Temporal reporting accuracy assessment of both FireCCI51 and C3SBA10 products. 


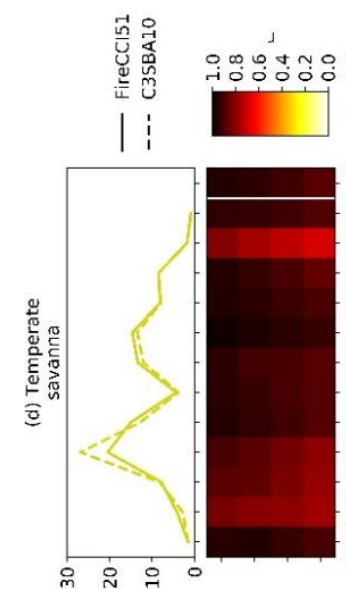

วdols

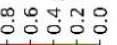
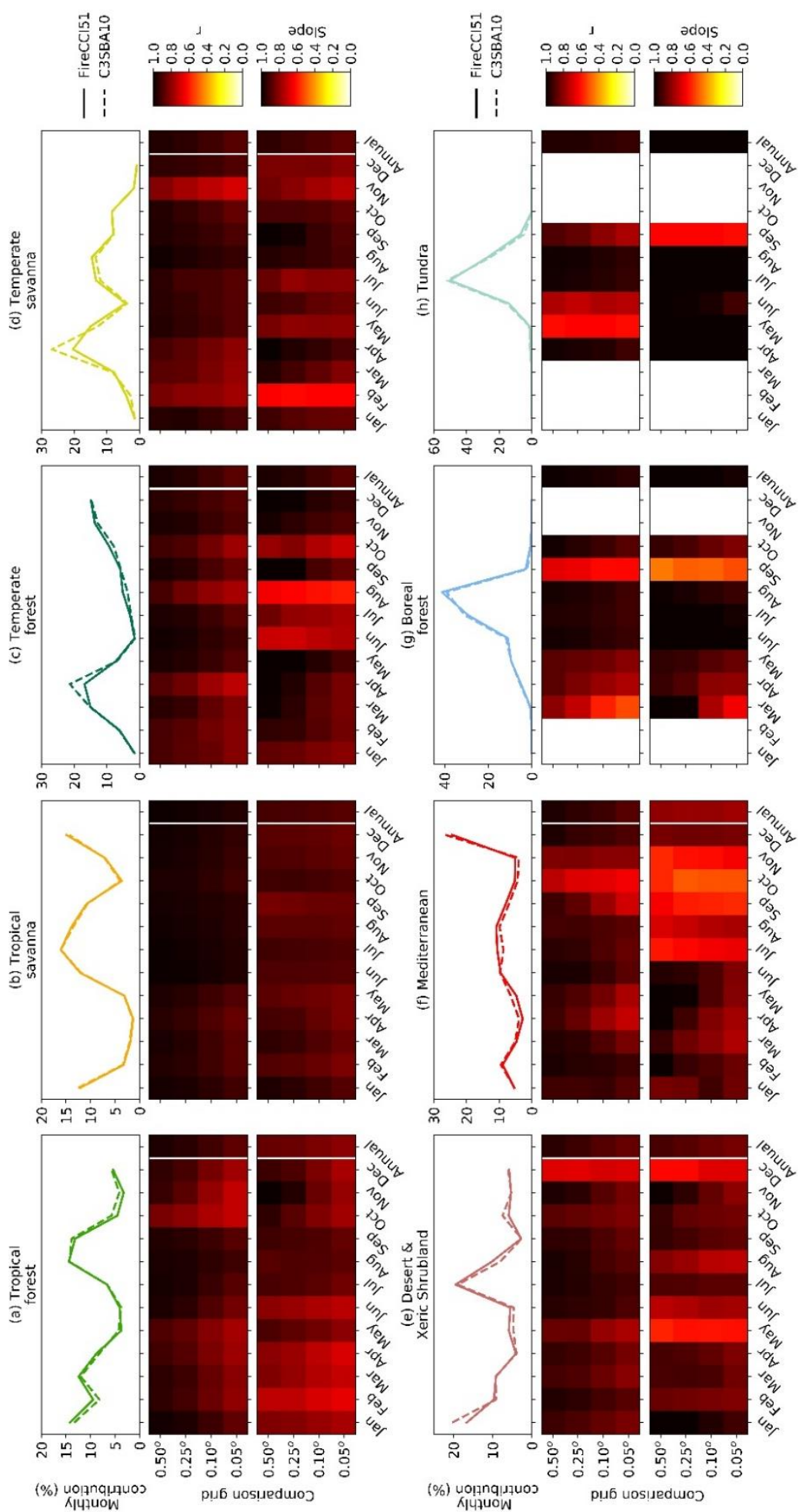

Figure 8. Monthly correlation between the FireCCI51 and C3SBA10 products per biome and grid size for the year 2019. 
https://doi.org/10.5194/essd-2020-399

Preprint. Discussion started: 14 January 2021

(c) Author(s) 2021. CC BY 4.0 License.

(c) (1)

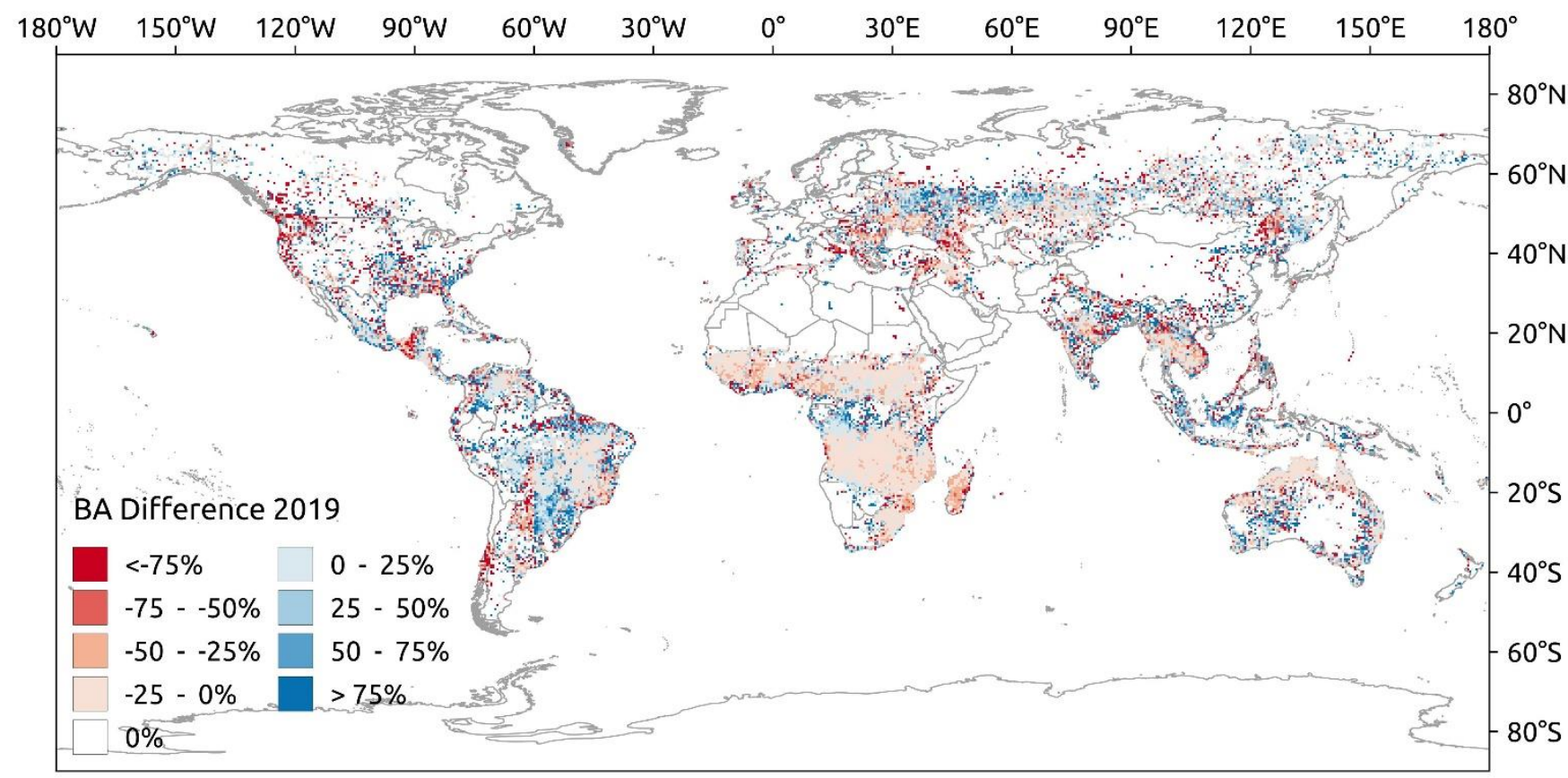

885

Figure 9. Proportional differences of burned area detection between the FireCCI51 and C3SBA10 at $0.5^{\circ}$ spatial resolution. The negative values (red) means that the FireCCI51 detected more burned area while the positive ones (blue) that the C3SBA10 detected more.

890

895 
https://doi.org/10.5194/essd-2020-399

Preprint. Discussion started: 14 January 2021

(c) Author(s) 2021. CC BY 4.0 License.

\section{Tables}

Table 1. OLCI bands characteristics. The band indicated in grey was the one used as input for the algorithm.

\begin{tabular}{llll}
\hline Band & Band centre $(\mathrm{nm})$ & Bandwidth $(\mathrm{nm})$ & MERIS heritage \\
\hline Oa01 & 400 & 15 & No \\
Oa02 & 412.5 & 10 & Yes \\
Oa03 & 442.5 & 10 & Yes \\
Oa04 & 490 & 10 & Yes \\
Oa05 & 510 & 10 & Yes \\
Oa06 & 560 & 10 & Yes \\
Oa07 & 620 & 10 & Yes \\
Oa08 & 665 & 10 & Yes \\
Oa09 & 673.75 & 7.5 & No \\
Oa10 & 681.25 & 7.5 & Yes \\
Oa11 & 10 & Yes \\
Oa12 & 708.75 & 7.5 & Yes \\
Oa13 & 753.75 & 2.5 & Yes \\
Oa14 & 761.25 & 3.75 & No \\
Oa15 & 764.375 & 2.5 & No \\
Oa16 & 767.5 & 15 & Yes \\
Oa17 & 778.75 & 20 & Yes \\
Oa18 & 865 & 10 & Yes \\
Oa19 & 885 & 10 & Yes \\
Oa20 & 900 & 40 & No \\
Oa21 & 940 & & No \\
\hline
\end{tabular}

905 
https://doi.org/10.5194/essd-2020-399

Preprint. Discussion started: 14 January 2021

(c) Author(s) 2021. CC BY 4.0 License.

(c) (1)

Table 2. Pixel and Grid products specifications.

\begin{tabular}{llll}
\hline Product & $\begin{array}{l}\text { Spatial } \\
\text { resolution }\end{array}$ & Layers & Description \\
\hline Pixel & $300 \mathrm{~m}$ & JD & Julian date or day of the year when the burned \\
pixel was detected \\
Confidence level of the classified pixel (both \\
burned and unburned) \\
\end{tabular}

Table 3. Burned area per biome derived from the C3SBA10 product, and relative differences against the predecessor global BA product FireCCI51.

\begin{tabular}{lrrrrrr}
\hline \multirow{2}{*}{ Biome } & \multicolumn{2}{c}{ C3SBA10 Burned area $\left(\mathrm{km}^{2}\right)$} & \multicolumn{3}{c}{ Difference C3SBA10-FireCCI51 } \\
& $2017^{*}$ & $2018^{*}$ & $2019^{* *}$ & $2017^{*}$ & $2018^{*}$ & $2019 * *$ \\
\hline Tropical savanna & 2782564 & 2801290 & 2701210 & $-17.7 \%$ & $-16.4 \%$ & $-9.5 \%$ \\
Tropical forest & 335032 & 313597 & 411926 & $-22.3 \%$ & $-17.6 \%$ & $-5.2 \%$ \\
Temperate savanna & 210382 & 135370 & 164995 & $-9.8 \%$ & $-3.9 \%$ & $-0.4 \%$ \\
Desert and xeric shrubland & 258622 & 148073 & 113707 & $-20.7 \%$ & $-19.4 \%$ & $-2.8 \%$ \\
Temperate forest & 89537 & 111662 & 110884 & $-8.9 \%$ & $-11.5 \%$ & $-1.0 \%$ \\
Boreal forest & 61173 & 74014 & 90503 & $+4.5 \%$ & $+2.4 \%$ & $+4.4 \%$ \\
Mediterranean & 27421 & 8884 & 24975 & $-18.9 \%$ & $-32.8 \%$ & $-16.8 \%$ \\
Tundra & 5734 & 1697 & 13044 & $+3.8 \%$ & $+4.1 \%$ & $+13.1 \%$ \\
\hline Global & 3770465 & 3594588 & 3631243 & $-17.3 \%$ & $-15.7 \%$ & $-7.8 \%$ \\
\hline
\end{tabular}

* Only S3A satellite available

** Both S3A and B satellites available 
https://doi.org/10.5194/essd-2020-399

Preprint. Discussion started: 14 January 2021

(c) Author(s) 2021. CC BY 4.0 License.

(c) (1)

Table 4. Accuracy metrics for the years 2017, 2018 and 2019. Standard errors are shown between parentheses.

\begin{tabular}{lllllll}
\hline \multicolumn{1}{c}{ Year } & \multicolumn{2}{c}{$2017^{*}$} & \multicolumn{2}{c}{$2018^{*}$} & \multicolumn{2}{c}{ 2019** } \\
& FireCCI51 & C3SBA10 & FireCCI51 & C3SBA10 & FireCCI51 & C3SBA10 \\
\hline Dice coefficient & $0.64(0.03)$ & $0.59(0.03)$ & $0.68(0.03)$ & $0.64(0.03)$ & $0.61(0.03)$ & $0.59(0.04)$ \\
Commission error & $0.23(0.03)$ & $0.23(0.03)$ & $0.17(0.02)$ & $0.14(0.02)$ & $0.22(0.02)$ & $0.20(0.02)$ \\
Omission error & $0.44(0.03)$ & $0.52(0.04)$ & $0.42(0.04)$ & $0.50(0.04)$ & $0.49(0.04)$ & $0.53(0.04)$ \\
Relative bias & $-0.27(0.05)$ & $-0.38(0.05)$ & $-0.31(0.04)$ & $-0.41(0.04)$ & $-0.35(0.04)$ & $-0.42(0.04)$ \\
\hline
\end{tabular}

$920 *$ Only S3A satellite available $\quad * *$ Both S3A and B satellites available

Table 5. Global correlation coefficient between FireCCI51 and C3SBA10, slope and RMSE for the years 2017,2018 and 2019 at $\mathrm{0.05}^{\circ}, \mathrm{0.10}^{\circ}, \mathrm{0.25}^{\circ}$ and $0.50^{\circ}$ grid size.

\begin{tabular}{lrrrrc}
\hline & \multicolumn{5}{c}{ Grid Size } \\
\hline $\mathrm{r}$ & & $0.05^{\circ}$ & $0.1^{\circ}$ & $0.25^{\circ}$ & $0.5^{\circ}$ \\
& $2017^{*}$ & 0.937 & 0.962 & 0.981 & 0.988 \\
& $2018^{*}$ & 0.943 & 0.966 & 0.983 & 0.989 \\
\hline slope & $2019^{* *}$ & 0.952 & 0.972 & 0.986 & 0.992 \\
& $2017^{*}$ & 0.823 & 0.836 & 0.844 & 0.847 \\
& $2018^{*}$ & 0.838 & 0.850 & 0.857 & 0.859 \\
& $2019^{* *}$ & 0.882 & 0.894 & 0.904 & 0.907 \\
\hline RMSE $\left(\mathrm{km}^{2}\right)$ & $2017^{*}$ & 1.347 & 4.029 & 17.810 & 57.404 \\
& $2018^{*}$ & 1.279 & 3.807 & 16.800 & 54.338 \\
& $2019^{* *}$ & 1.073 & 3.060 & 12.577 & 38.092 \\
\hline
\end{tabular}

925 
https://doi.org/10.5194/essd-2020-399

Preprint. Discussion started: 14 January 2021

(c) Author(s) 2021. CC BY 4.0 License.

(c) (1)

Table A1. Average (2017-2019) temporal reporting accuracies of the C3SBA10.

\begin{tabular}{llllllllll}
\hline $\begin{array}{l}\text { Reporting } \\
\text { accuracy }\end{array}$ & $\begin{array}{l}\text { Tropical } \\
\text { forest }\end{array}$ & $\begin{array}{l}\text { Tropical } \\
\text { savanna }\end{array}$ & $\begin{array}{l}\text { Temperate } \\
\text { forest }\end{array}$ & $\begin{array}{l}\text { Temperate } \\
\text { savanna }\end{array}$ & $\begin{array}{l}\text { Desert \& } \\
\text { xeric } \\
\text { shrubland }\end{array}$ & $\begin{array}{l}\text { Medite- } \\
\text { ranean }\end{array}$ & $\begin{array}{l}\text { Boreal } \\
\text { forest }\end{array}$ & Tundra & Global \\
\hline 0-1 days & $18.4 \%$ & $20.1 \%$ & $14.3 \%$ & $22.6 \%$ & $26.8 \%$ & $14.8 \%$ & $7.0 \%$ & $8.4 \%$ & $18.8 \%$ \\
$0-3$ days & $42.3 \%$ & $49.5 \%$ & $33.0 \%$ & $49.4 \%$ & $57.2 \%$ & $37.9 \%$ & $18.5 \%$ & $20.4 \%$ & $45.4 \%$ \\
$0-5$ days & $61.4 \%$ & $69.5 \%$ & $51.1 \%$ & $68.2 \%$ & $75.4 \%$ & $59.5 \%$ & $33.0 \%$ & $34.7 \%$ & $64.6 \%$ \\
$0-10$ days & $85.5 \%$ & $90.8 \%$ & $80.3 \%$ & $91.9 \%$ & $94.1 \%$ & $91.0 \%$ & $70.0 \%$ & $69.3 \%$ & $88.1 \%$ \\
\hline
\end{tabular}

